\title{
A catalog of the types of Tenebrionidae sensu lato (Insecta, Coleoptera, Cucujiformia) deposited in the Museo Argentino de Ciencias Naturales "Bernardino Rivadavia," Buenos Aires
}

\author{
Axel O. BACHMANN ${ }^{1} \&$ Gustavo E. FLORES ${ }^{2}$ \\ ${ }^{1}$ Entomology Division, MACN, CONICET (Museo Argentino de Ciencias Naturales) Av. A. Gallardo 470, \\ C1405DJR, Buenos Aires. e-mail: bachmann@bg.fcen.uba.ar. ${ }^{2}$ Laboratory of Entomology, IADIZA, \\ CCT-CONICET, Mendoza (Instituto Argentino de Investigaciones de las Zonas Áridas) Casilla de correo 507, \\ 5500-Mendoza. e-mail: gflores@lab.cricyt.edu.ar
}

\begin{abstract}
The type specimens (all current categories) of Tenebrionidae s.l. housed at the Museo Argentino de Ciencias Naturales "Bernardino Rivadavia," until December 2007 are listed; 158 names are recorded, 125 of them (79 percent) represented here by name-bearing types ('primary' types). The family is taken in its broadest sense (including the Alleculinae and Lagriinae, sometimes treated as separate families). The specific and subspecific names were alphabetically filed, followed by the generic ones as they were spelled in the original publication (or the generic and specific names in the case of subspecies and varieties). Later combinations and/or current binomina, and synonyms are mentioned as far as these are known to the authors. Two lists are added: 1 . of specimens labelled as types of names not found in the literature, and presumably not published, and 2. of specimens labelled as types, but not originally included as such, and published or not after the original description.
\end{abstract}

Key words: Tenebrionidae, type specimens, Argentina.

Resumen. Catálogo de los tipos de Tenebrionidae sensu lato (Insecta, Coleoptera, Cucujiformia) depositados en el Museo Argentino de Ciencias Naturales "Bernardino Rivadavia", Buenos Aires. Se catalogan los ejemplares típicos de todas las categorías aceptadas, de Tenebrionidae s.l. depositados en este museo hasta diciembre 2007; se registran 158 nombres, 125 de ellos ( 79 por ciento) representados aquí por tipos portadores de nombres (tipos 'primarios'). La familia se toma en su concepto más amplio (incluyendo a las Allecullinae y Lagriinae, a veces tratadas como familias separadas). Los nombres específicos y subespecíficos fueron ordenados alfabéticamente; a estos siguen los de los géneros, así como se publicaron originalmente, o de los géneros y especies en el caso de las subespecies y variedades. Se mencionan las combinaciones ulteriores y/o los binomios en uso, y los sinónimos, hasta donde son conocidos por los autores. Se agregan dos listas: 1. de los ejemplares rotulados como tipos, de nombres no hallados en la bibliografía, y presumiblemente no publicados, y 2. de los ejemplares rotulados como tipos, pero no incluidos originalmente como tales, publicados o no después de la descripción original.

Palabras clave: Tenebrionidae, especímenes tipo, Argentina.

A catalog of the typical specimens (all current categories) of species of Tenebrionidae $s$. l. deposited in the Entomological Division of the Museo Argentino de Ciencias Naturales "Bernardino Rivadavia," until December 2007 is presented; it contains 158 names represented by 26 holotypes, 98 syntypes (1 of them dubious) of 59 names, 40 lectotypes, 167 paratypes, one of them dubious (including 5 allotypes), and 24 paralectotypes; 125 of these 158 names (79 percent) are here represented by name bearing types ('primary types'). One holotype is missing on the holding card, that of Lepidocnemeplatia vianai Kaszab, but the entry is included in the main list.

The family is here taken in its broadest sense, including the Alleculinae and the Lagriinae, sometimes treated as separate families. We adopt the classification presented by Aalbu (2006) which has incorporated, when relevant, the nomenclatural changes proposed by Bouchard et al. (2005).

Specific and subspecific names are alphabetically entered in a single list, as it is usual in type specimen catalogs; each name is followed by the generic one (and subgeneric one if it was mentioned) as it was spelled in the original binomen, or by the generic and specific names in the case of subspecies or 'varieties'; a bibliographic citation follows, as well as a listing of the types if these were mentioned. An account of the type specimens actually housed at the Museum follows, with their label data. According to the International Code of Zoological Nomenclature (ICZN, 1999), allotypes are not 'name bearing types'. If the country is not mentioned, Argentina is meant; in every 
other case, the country is mentioned first. Some specimens bear a registration number, entered in the Entomology Division register; numbers under 10000 correspond to the old general register of the Museum. Posterior nomenclatural or taxionomical changes are recorded as long as these are known to the authors. Unless otherwise stated, the specimens mentioned are pinned. Words or whole sentences in square brackets [ ] are our own comments, not included in the originals quoted.

For the identification of types not formally designated in the original publication (art. 72.4 of the Code), evidences from the labels are considered. When the authors did not formally designate a holotype, or its equivalent, and did not mention the amount of specimens examined, it is assumed that they had a series of syntypes (recommendation $73 \mathrm{f}$ of the Code), eventually 'sole syntypes'.

Some specimens in the collection are labelled as types of names not found in the literature, and assumed not to have been published. These names are probably not available in the sense of the Code; however, in order to assist in future research, they are separately listed.

Specimens labelled as types or cotypes, but not included in the original publication, and specimens designated as types after the original publication date, published or not, cannot be accepted as a part of the type series; however, also in order to assist in future research, they are included in a third list.

Hermann Burmeister (the first scientific director of the Museum, since 1861) never labelled his specimens as types, their condition can only be inferred from the collection, and from his publications. He put a label with the name of the species fastened to the bottom of the drawer, to the left of the specimen or series; frequently he put a locality label only to the first specimen, or to a few, so it can only be suspected that the following ones pertain to the same series; often the label has an indication of the distribution, sometimes very vague, like "Argentina". He did not mention in his publications how many specimens he examined (except for single ones) so we assume them to be syntypes (recommendation $73 \mathrm{f}$ of the Code). One of us (AOB) added a "Typus" or "Syntypus" red label, and the original name given by Burmeister.

Carlos Berg, follower of Burmeister as an entomologist in the Museum, and the director after his death in 1892, was more careful in labelling types: he used to put a very small red-ink-printed label reading "Typus" within a red frame, and usually vague locality labels printed on dark green paper, like "Mendoza" or "Patagonia".
Carlos Bruch put in his personal collection very small white cardboard labels with country, province, and date, printed with black ink, within a black frame. His identification labels were handwritten on white paper with a red frame; those of his last years were green framed. He used to provide the types with a small piece of paper handwritten by their authors, probably cut from a letter, with the name of species, so adding credibility of the type condition of the specimens; the generic name is seldom, and then only partially conserved, which explains our expression "with remainings of...' in the catalog. His "Typus" and "Cotypus" labels were printed on pale green paper, and those of the last years were handwritten on similar pale green paper; only a few ones were handwritten on pink paper. We suspect that some of the 'cotypes' in the Bruch collection deposited in this museum were not even included in the typical series, but it is not possible now to assure in every case their condition. In order to assist in future research, we include them in the present paper as syntypes or as paratypes, explaning the decision in a 'note'.

This Museum is identified by MACN. Other collections are identified as follows: AMNH, American Museum of Natural History, New York, USA; BM, Natural History Museum, London, U.K.; BR, C. Bruch coll., in MACN; CB, C. Berg coll., one minor part included in $\mathrm{HB}$; the main portion (originally at the University of Buenos Aires) is in part in MACN and in part in MLP; ERT, E.R. Trémouilles coll.; the types were deposited in MACN; FIML, Fundación e Instituto Miguel Lillo, Tucumán, Argentina; FMNH, Field Museum of Natural History, Chicago, USA; HB, H. Burmeister coll., in MACN; IAD, Instituto Argentino de Investigaciones de las Zonas Aridas, IADIZA, Mendoza, Argentina; JB, J. Brèthes coll., in MACN; LP, L.E. Peña coll., now in FMNH; MF, Museum Frey, Tützing, Germany, now in NHMB; MLP, Museo de La Plata, Argentina; NHMB, Natural History Museum, Basel, Switzerland; MNS, Museo Nacional de Historia Natural, Santiago, Chile; HNHM, Hungarian Natural History Museum, Budapest, Hungary; MNHN, Muséum National d'Histoire Naturelle, Paris, France; MT, Museum of Transvaal, Pretoria, Southafrica; PM, Peabody Museum of Natural History, Yale University, USA; UC, Universidad de Concepción, Concepción, Chile.

Other abbreviations used in the main body of the catalog are: allot., allotype; coll., collection; det., determined; des., designated; fem., female; gob., gobernación (federal territory); handwr., handwritten; holot., holotype; lectot., lectotype; paralect., paralectotype; parat., paratype; prov., province; spec., specimen; synt., syntype. 


\section{CATALOG OF THE TYPES}

abnormis [Epipedonota] Burmeister 1875: 476. 1 spec. [Santa Cruz Prov.] Santa Cruz River mouth, Berg leg.

Holot., "S. Cruz / Patag."; "Psectrascelis / sulcicollis / Wat." handwr. by L.E. Peña. One of us (AOB) added: "Holotypus" printed, and "Epipedonota / abnormis / Burmeister 1875 / Typus" handwr., both on red cardboard. Ex HB.

Notes: Synonymized with Nyctelia sulcicollis Waterhouse 1841 (currently in Psectrascelis) by Burmeister (1877: 71); revalidated and transferred to Psectrascelis by Gebien (1937: 751); synonymized with Psectrascelis sulcicollis (Waterhouse 1841) by Kulzer (1954: 186).

acuticollis [Diastolinus] Fairmaire 1905: 299. Chaco and Misiones.

2 synt. "Rep. Argentina/Gob. Chaco / XII.1894

/ C. Bruch" printed on white cardboard, date handwr. One of them: "Diastolinus / acuticollis / Fairm. tipo" handwr. by Bruch, with a red frame; "Opatrinus / validus / Burm. / 1875 [handwr. by Bruch] / C. Bruch determ. [printed]" on white paper, and "Diastolinus acuticollis" handwritten by Fairmaire, cut. The other one: "Typus" printed on pale green paper. One of us (AOB) added "Diastolinus / acuticollis / Fairmaire 1905" handwr. on red cardboard. Ex BR.

Note: Synonymized with Opatrinus validus Burmeister 1875 by Gebien (1938: 297).

aenea [Statiropsis] Borchmann 1912: 389-390. 1 spec. Misiones, leg. Jörgensen; 1 spec. Brasil XII.1901 ex coll. Bruch; 1 spec. without locality label.

1 synt. glued to a card "Rep. Brasil / XII.1901 / C. Bruch" printed on white cardboard, date handwr.; "Typus" printed on pale green paper; "Statiropsis / aenea / Borchm." handwr. by Bruch, with a red frame; "Statiropsis n.g. / aenea" handwr. by Borchmann?, cut, with remainings of a black frame. Ex BR.

amabilis [Gyriosomus] Kulzer 1959: 535-537, pl. 11: f. 5, 6. Chile: Coquimbo: Llano de la Higuera, in the desert IX.1954, 14.X.1957; NE of Tofo 27.X.1957; Choros Bajos 2.X.1957. Holot. and parat. in LP, parat. in MF and MT.

1 parat. "Llano Higuera / $67 \mathrm{Km} \mathrm{N}$ Serena / Coquimbo E. Tofo 29 Septiembre 1954 / Leg. R.
Wagenck" printed on white paper; "Paratypus" printed on red paper; "Gyriosomus amabilis, Klz." handwr. on white paper.

andinus [Nycterinus] Peña 1971: 140-141, pl. i: 9, iii: G, iv: g. Chile: Coquimbo. Holot., allot. and 35 parat. in LP; parat. in several coll.

2 parat., one of them "Prov. Coquimbo / Los Molles 1800, 2000 Mt. / 2.Oct.1967 / Coll. L.E. Peña" printed on white paper; the other "Coquimbo / Rivadavia / Febr. 1947"; both: "Paratypus" printed on orange-red paper; "Nycterinus / andinus / nov. sp. [handwr.] / Det. L.E. Peña 1970 [printed]" on white paper.

angusta [Epipedonota] Burmeister 1875: 479. Catamarca.

Lectot. and 2 paralectot. "Catamarca" printed on green paper, reverse white; "Epipedonota angusta / Burmeister / Lectotypus [on one] Paralectotypus [on two] / G. Flores \& P. Vidal Des. 1999" printed on red paper. One of us (AOB) had previously added "Epipedonota / angusta / Burmeister 1875 / Syntypus" handwr. on red cardboard. Ex HB.

Note: Gebien (1937: 749) downgraded it to a subspecies, E. monilis angusta; Kulzer (1954: 161) recorded it as E. monilis angustata [sic], an incorrect spelling; Flores \& Vidal (2001: 32-33) designated lectot. and 2 paralectot., and synonymized angusta with microdera Burmeister (1875: 479).

angustus [Opatrinus] Burmeister 1875: 499. Santa Fe.

3 synt., 2 of them (one lacks the head) "Sta. Fé" printed on green paper, reverse white, the $3^{\text {d }}$ one without locality label. One of us (AOB) had added "Syn- / typus" and "Opatrinus / angustus / Burmeister 1875 / Syntypus" handwr. on red cardboard. Ex HB.

argentina [Psectrascelis] Flores 2007b: 92, f. 1-2, 5-6. Holot., allot., parat. in IAD: San Juan, Parque Nac. El Leoncito, 3510 m Cno. Portezuelo, Sierra del Tontal, 25.XI.2003 leg. G. Flores; 3 parat. in MACN: San Juan, Barreal 3376 m, 25.I.2006 leg. Compagnucci, Ojanguren, Piacentini.

3 parat. 1 male, 2 females; the male: "Arg. San Juan / Barreal 3376 m / 25.I.2006 Compagnucci / Ojanguren, Piacentini" and "31931'49' 'S / $69^{\circ} 13^{\prime} 10^{\prime \prime}$ 'W" printed on white paper; "Psectrascelis / argentina n. sp. / Paratypus male / Det. G. 
Flores 2007" printed on red card; the females idem data but "Paratypus female".

austera [Camaria] Berg 1883a: 76-77. 1 spec. Gran Chaco, leg. Fontana, in $\mathbf{C B}$; 1 spec. Tucumán, at the University [of Buenos Aires].

1 synt. "Tucumán" printed on green paper, reverse white; "Typus" printed with red ink on white paper; "Camaria / austera / Berg" handwr. by Berg on white paper with a red frame. One of us (AOB) had added "Camaria / austera / Berg 1883 / Syntypus" handwr. on red cardboard. Ex CB.

Notes: In MLP there is a syntype labelled "Typus" and "Chaco". Transferred to Blapida by Gebien (1942: 325).

australis [Falsopraocis] Flores 2000a: 67-68, f. 5, 10, 15, 20, 21, 30. Mendoza: Las Cuevas, holot. male; Chile: Aconcagua, allot. female, both in FMNH; parat. with the same data as allot., MACN, IAD, and several other institutions.

2 parat., one of them, "Lag. de Castro / Aconcagua / 3200 m" printed; "8-11.Dic.1958 / Coll.: L.E. Peña" printed; the other one "Chile [obverse] / 57 / 68 [reverse]" handwr. on a pale gray paper disc; both: "Paratypus" printed on red paper; "Falsopraocis / australis n.sp. / Det. G. Flores 2000" printed on white paper.

australis [Nycterinus rugiceps subsp.] Peña 1971: 139, pl. i: 8, iii: F, iv: f. Chile: Santiago: cerro S. Cristóbal; Aconcagua; Valparaíso; holot. in LP, allot. in MNS, parat. in FIML and several other institutions.

1 parat. "Zapallar / Prov. Aconcagua / 17-Junio 1968 / Coll.: L.E. Peña” printed on white paper; "Paratypus" printed on orange-red paper; "Nycterinus / rugiceps / australis / nov. ssp. / Det. L.E. Peña 1970" printed on white paper.

barbatus [Ecnomoderes] Gebien 1928: 111, pl. ii: 2. Catamarca: Cerro Colorado, leg. Weiser, 4 spec. sent by Bruch, in whose collection there are further spec.; the photograph was taken by Bruch.

4 synt. (all?) glued to cards, on one pin "Cerro Colorado / Catam. Weiser" handwr. by Bruch; "Typus" printed on pale green paper; "Ecnomoderes / barbatus / Geb." handwr. by Bruch, with a red frame. Ex BR.

Notes: There are 2 further spec., "Santa María / Catamarca" handwr. by Bruch, one of them
"Cotypus" printed on pale green paper, the other one "Foto" printed on pale green paper (this is the spec. illustrated by Gebien). L.E. Peña (letter of 29.VIII.1991) says the type is in MF. As Gebien mentioned only 4 specimens, some doubt is here expressed about the four spec. on one pin.

barrosi [Pilobalia] Peña 1973: 164-168, f. 1, 6, 10, 14, pl. 1: B. Salta: Cachipampa $3200 \mathrm{~m}$, 5.II.1970 (and 8.X.1968) leg. Peña \& Barros; holot., allot., 225 parat. in LP, 2 parat. in MACN, some in FIML, MNS, and several other institutions.

2 parat. "Cachipampa / 3200 m. Salta / Argentina / 5-Febr.-1970 / Coll.: L.E. Peña" printed on white paper; "Paratypus" printed on orange-red paper; "Pilobalia / barrosi / nov. sp. / det.: L.E. Peña 1971" printed on white paper.

biaculeata [Camaria] Fairmaire 1905: 301-302. Catamarca. [The measurements are given as a range, suggesting several spec.]

1 synt. (?) "Rep. Argentina / Prov. Tucumán / VI.1903 / C. Bruch” printed on white cardboard, date handwr.; "Typus" printed on pale green paper; "Camaria / biaculeata / Fairm. tipo" handwr. by Bruch, with a red frame; "Camaria / biaculeata Fm. n. sp." handwr. by Fairmaire, cut. Ex BR.

Notes: The localities differ, but otherwise the type condition seems legitime. Transferred to Blapida by Gebien (1942: 325).

bicarinata [Praocis] Burmeister 1875: 495-496. Patagonia, río Santa Cruz, taken by Berg.

Lectot. and 3 paralectot. "S. Cruz / Patag." printed on green paper, reverse white, one of them with "67" printed on green paper; "Lectotypus [on one] Paralectotypus [on three] / Praocis bicarinata/ Burmeister, 1875/ Des. G. Flores 2006" printed on red paper; additional labels handwr. on white paper, in the lectot. "sex: male/ Det. G. Flores", one paralectot. not sexed and the other two "sex: female/ Det. G. Flores", one of this with a label: "Praocis / fimbriata / Burmeister, 1875 / Det. G. Flores 2006" handwr. on white paper. One of us (AOB) had previously added to all four "Praocis / bicarinata / Burmeister 1875 / Syntypus", handwr. on red cardboard. Ex HB.

Notes: There are two further spec. without locality labels, one of them with " 26 " printed on green paper; they may also belong to the original series. Currently in Praocis (Praonoda). Flores (2007a: 419) designated lectot. and 3 paralectot. 
bifoveata [Nyctelia] Fairmaire 1905: 294. Catamarca.

Lectot. "Rep. Argentina / Prov. Catamarca / XII.1896 / C. Bruch" printed on white cardboard, date handwr.; "Typus" and "Foto" printed on pale green paper; "Nyctelia / bifoveata / Fair. tipo" handwr. by Bruch, with a red frame; "bifoveata Fm. n. sp." handwr. by Fairmaire, cut, there are remainings of "Nyctelia"; "Lectotypus / Nyctelia bifoveata / Fairmaire, 1905 / Des. G. Flores 2005" handwr. on red paper. Ex BR.

Notes: Considered by Kulzer (1963: 68) as incertae sedis; in his revision of Nyctelia he did not examine the type specimen. Flores (2007a: 416) designated lectot. and synonymized $N$. bifoveata with N. vageimpressa Fairmaire (1904: 62).

biramosa [Epipedonota] Berg 1901: 271. Patagonia: Río Negro and Neuquen, 2 spec. in MACN, 1 in CB.

Lectot. and 2 paralectot., two of them "Neuquen", handwr. on green paper; the lectot. "biramosa Berg 1901" ex HB, one paralectot. "Epipedonota biramosa Berg" handwr. by Berg (ex CB); the other paralectot. "Rca. Argentina / Gob. Rio Negro / III.1898 / C. Bruch" printed on white cardboard, date handwr. Ex HB. "Epipedonota biramosa / Berg / Lectotypus [on one] Paralectotypus [on two] / G. Flores \& P. Vidal Des. 1999" printed on red paper. One of us (AOB) had previously added on all of them: "Epipedonota / biramosa / Berg 1901 / Syntypus" handwr. on red cardboard.

Notes: Considered as a subspecies of E. ebenina by Gebien (1937: 749); upgraded to species rank, synonymized with $E$. nitida (Philippi \& Phillipi 1864), and lectot. and paralectot. designated by Flores \& Vidal 2001: 34-35. Recorded as E. ebenina biraminosa [sic] by Kulzer (1954: 164, 171, an incorrect spelling).

blapoides [Nyctelia] Fairmaire 1905: 293. Río Negro.

Lectot. "Rep. Argentina / Gob. Río Negro / 7.II.1898 / C. Bruch" printed on white cardboard, date handwr.; "Typus" and "Foto" printed on pale green paper; "Nyctelia / blapoides / Fair. tipo" handwritten by Bruch, with a red frame; "Nyctelia
/ blapoides / Fm. n. sp." handwr. by Fairmaire, cut; "Lectotypus / Nyctelia / blapoides / Fairmaire, 1905 / Des. G. Flores 2006” printed on red paper. Ex BR.

Note: Flores (2007a: 421) designated lectot.

boliviana [Epipedonota] Flores \& Vidal 2001: 8, 19, f. 34. Bolivia: Tarija: Villa Abecia, holot., male in MACN, allot. fem., in MNS, 12 parat. in MF, IAD, FIML, coll. Vidal.

Holot. "Villa Abecia / 2400 m 11-III-76 / Tarija, Bolivia / Coll. L.E. Peña" printed on white paper; "Epipedonota / boliviana / sp. n. / Holotypus male / G. Flores - P. Vidal 2000” printed on red paper.

bothriocephalus [Crypticus] Gebien 1928: 117118. Jujuy 30.VII.1906 leg. Bruch, 2 males, 1 fem., sent by Bruch; Paraguay: Trinidad leg. Zürcher, sent by Wagner, Berlin.

2 synt. glued to cards, on 2 pins, "Rep. Argentina / Prov. Jujuy / 30.VII.1906 / C. Bruch" printed on white cardboard, date handwr.; "Typus" (on one), "Cotypus" (on the other) printed on pale green paper; "Crypticus / bothriocephalus / Gebien" handwr. by Bruch, with a red frame. Ex BR.

Notes: There are no labels handwr. by Gebien; Peña (letter of 29.VIII.1991) says the type is in MF. Locality and date are as in the original description, but one or both may be no true types. Transferred to Gondwanocrypticus by Español Coll (1955: 10-11).

brevipilis [Antofagapraocis] Flores 2000a: 71-73, f. 7, 12, 17, 26, 27, 29, 30. Chile: Region II: Tumbre, holot., allot., 9 parat. in FMNH; Chile: Region I; Argentina: Salta: Pocitos; Jujuy?: Jache, other parat. in MACN (8), MNS, FMNH, IAD and other institutions.

8 parat.; on two of them: "Tumbre / SW Vn. Lascar / Prov. / Antofagasta”, "27 Enero 1969 / Coll. F. Sosa" printed; on two: "Tumbre 3500 ? m/ W Vn. Lascar / Antof. Enero-53 / Leg.: F. Sosa"; on three: "Sr. Ag. Calientes / (E) Catalina Ant.", "3800 m 29-XI-75 / Coll. L.E. Peña G." both printed; on one: "Argentina - Salta / 80-120 Kms. S. Los / Pocitos 3800, 3900 m" printed. On all: "Paratypus" printed on red paper; "Antofagapraocis / brevipilis n. sp. / Det. G. Flores 2000" printed on white paper. 
breyeri [sub Breyeri] [Lobopoda] Brèthes 1910: 206. Bolivia.

1 synt. glued to a card, with a pin-hole in the right elytron (it was previously pinned) "Bolivia" handwr. on green paper, reverse white; "Repreparo / M. Viana / I-1960" handwr. on white cardboard; "10257" handwr.; "Lobopoda / Breyeri / Brèthes" handwr. by Brèthes; one of us (AOB) added "Typus" printed on red cardboard. 3 parat. glued to cards, on 3 pins, "Col. / A. Breyer" printed on white paper; "Paratypus" printed on green paper. Two of them have a small round disk of pink paper, and one of these also "Lobopoda / breyeri / Breth. [handwr.] / Det. Köhler [printed]".

breyeri [sub Breyeri] [Scotobiopsis] Brèthes 1910: 207-208. Bolivia.

3 synt., 2 of them glued to cards, both with a pin-hole in the right elytron (as they were previously pinned), "Bolivia" handwr. on white paper; "Repreparo / M. Viana / I-1960" handwr. on white cardboard; "Scotobiopsis / Breyeri Brèthes" handwr. by Brèthes; one of these also "10255" handwr. The $3^{\text {d }}$ one pinned, "Col. / A. Breyer" printed; "Scotobiopsis n.g. / breyeri Brèthes n.sp. [obverse] / Type [reverse]" handwr. by Bruch? on orange paper; "Scotobiopsis Breyeri Brèthes" handwr. by Brèthes. One of us (AOB) added to all three "Syntypus" handwr. on red cardboard.

bruchi [sub Bruchi] [Allecula] Pic 1929: 183. Catamarca: La Ciénaga, leg. Weiser in BR and coll. Pic.

3 synt. glued on cards, on 2 pins, "La Ciénaga (Belén) / Catamarca I.1926 / Weiser Wolters leg." printed, date handwr.; "Typus" handwr. by Bruch on pale green paper; the pin with 2 spec. also "Allecula / Bruchi / Pic" handwr. by Bruch, with a green frame; "Allecula / Bruchi s.sp." handwr. by Pic?, cut. The pin with 1 spec. (head separated and glued to the locality label) one of us (AOB) added: "Allecula / Bruchi / Pic 1929 / Syntypus" handwr. on red cardboard.

bruchi [sub Bruchi] [Cuphotes] Pic 1930a: 179. Misiones, sent by Bruch.

1 synt. "Rep. Argentina / Gob. Misiones / 1.1897 [?] / C. Bruch" printed on white cardboard, date handwr.; "Typus" handwr. by Bruch on pale green paper; "Cuphotes / Bruchi / Pic" handwr. by Bruch; "Cuphotes / Bruchi n. sp." handwr. by Pic?, cut. Ex BR.

Note: After Peña (letter of 29.VIII.1991) the type should be in MNHN.

bruchi [sub Bruchi] [Derosalax] Gebien 1926: 86, pl. 2: f. 3. Catamarca: Famabalasto, leg. Weiser, 1 spec. in coll. Gebien; 1 spec. in coll. Bruch, not seen by Gebien, but identified by him through the photograph taken by Bruch.

1 synt. glued to a card "Famabalasto / Catam. Weiser" handwr. by Bruch; "Typus" and "Foto" printed on pale green paper; "Derosalax / Bruchi / Geb." handwr. by Bruch, with a red frame; "7" handwr. on pink paper. Ex BR.

Note: Gebien mentioned this specimen, identified by him through the photograph taken by Bruch (Gebien, 1926: 86 and f. 3).

bruchi [sub Bruchi] [Ecnomoderes] Gebien 1928: 112, pl. ii: 3. Neuquen: Plaza Huincul leg. Schiller 5.IV.1920, 1 spec. in coll. Gebien; Chubut: Comodoro Rivadavia leg. Schiller, not seen by Gebien, but identified through the photograph taken by Bruch (Gebien 1928: f. 3).

1 synt. glued to a card, "Plaza Huincul / Río Negro [sic] / Dr. Schiller" handwr. by Bruch [Plaza Huincul is in Neuquen Prov., not in Río Negro]; "Foto" printed on pale green paper; "Ecnomoderes / Bruchi / Geb." handwr. by Bruch, with a red frame; "1" handwr. on pink paper. Ex BR.

Notes: Gebien mentioned the spec., that he identified through the photograph taken by Bruch. There are several further spec.; two of them are pinned, each with an ant, from the same locality, date and collector, labelled "Cotypus", which seem not to have been seen by Gebien. Peña (letter of 29.VIII.1991) says the type is in MF.

bruchi [sub Bruchi] [Ectomopsis] Fairmaire 1905: 300. Catamarca.

1 synt. "Rep. Argentina / Prov. Catamarca / II.1897 / C. Bruch" printed on white cardboard, date handwr.; "Typus" printed on pale green paper; "Ectomopsis / Bruchi / Fairm." handwr. by Bruch, with a red frame; "Entomopsis Bruchii Fm. Plata [?]" handwr. by Fairmaire?, cut. Ex BR.

bruchiana [sub Bruchiana] [Allecula] Borchmann 1930b: 87-88, pl. iii: 4. Córdoba: Alta Gracia XI.-XII.1921, leg. Bruch, several females. 
6 synt. glued to cards, on 3 pins $(2+3+1)$ "Alta Gracia. La Granja / Sierras de Córdoba / XII.921 [on two pins, the other one 5.II.927] / C. Bruch leg." printed, dates handwr.; "Typus" printed on pale green paper, on two pins, "Fototipo" handwr. on pale green paper on the $3^{\mathrm{d}}$ one; "Allecula / Bruchi / Borchm." handwr. by Bruch, with a red frame on the first two; "Allecula / Bruchiana / Borchm." similar but without frame on the $3^{\mathrm{d}}$ one. On the $1^{\text {st }}$ one, in addition "Allecula / Bruchi" handwr. by Borchmann?, cut. Ex BR.

Note: The $3^{\text {rd }}$ spec. does perhaps not pertain to the typical series. Note that some spec. are labelled bruchi, not bruchiana as spelled in the publication.

bruchianum [sub Bruchianum] [Phrynocarenum] Gebien 1928: 107-109, pl. ii: 1. San Luis: Alto Pencoso II.1904 leg. Bruch, 1 spec. in coll. Gebien, now in NHMB; 1 spec. in coll. Bruch; after Bruch in litt. 16.VIII.1927, Weiser and Wolters obtained the species in Catamarca: La Ciénaga. Not seen [by Gebien], but identified through the photo taken by Bruch [and published by Gebien (1928: tab. II, 1)].

2 spec. (1 is a synt.) "Rep. Argentina / Prov. San Luis / 190_/C. Bruch" printed on white cardboard; "Typus" printed on pale green paper, one of them "Foto" printed on pale green paper; "Phrynocarenum / Bruchianum / Geb." handwr. by Bruch. Ex BR.

Notes: Only one spec., the one with the label "Foto", must be considered as a syntype, identified by Gebien through the photo taken by Bruch, and published by Gebien (1928: pl. II, 1). Synonymized with Emmallodera strangulata Fairmaire 1905 by Marcuzzi (1976: 117), who stated that Gebien (1928) apparently did not know Fairmaire's species and considered the new taxon to be a new genus and species, and named it Phrynocarenum strangulatum (Fairmaire 1905), a name that is now valid; this species had been transferred to Pseudoscotobius by Kulzer (1955: 397). One of us (GEF) had the opportunity to examine a syntype from the Gebien coll., now in NHMB, labelled "Rep. Argentina / Prov. San Luis / 190_ / C. Bruch", "Type No 1341", "Phrynocarenum / Bruchianum / Geb.", "Phrynocarenum / Bruchianum / Type Geb.". Curiously both spec. lack any reference to the locality or to the date, Alto Pencoso, II.1904. camponotophilus [Lystronychus (Lystronychus)] Borchmann 1930a: 105-106. Córdoba: Alta Gracia, 2 spec. II, III.1921 ex coll. Bruch; 1 spec. Córdoba, in nests of Camponotus rufipes var. magnifica [Hymenoptera, Formicidae].

3 synt. glued on cards, on 3 pins. One of them "Rep. Argentina / Prov. Córdoba / 190_/C. Bruch" printed on white cardboard; "Typus" printed on pale green paper; "Lystronychus / camponotophilus / Borchm." handwr. by Bruch, with a red frame; "Lystronychus / camponotophilus n.sp." handwr. by Borchmann?. The second one: an ant glued to a card; "Alta Gracia. La Granja / Sierras de Córdoba / XII.921 C. Bruch leg.” printed, date handwr.; "en nido de [in nest of] Camponotus rufipes var. magnifica" handwr. by Bruch; "Typus" printed on pale green paper. One of us (AOB) added "Lystronychus / camponotophilus / Borchmann 1930 / Syntypus" handwr. on red cardboard. The third one: "Cotypus" printed on pale green paper, the other labels similar to the $1^{\text {st }}$ one, but without a frame. Ex BR.

cantillana [Callyntra] Flores \& Vidal 2000: 188191, f. 1, 3. Chile: Metropolitan Region: Alto de Cantillana: Villa Alhue and other localities in the same Region and Region VI, holot., allot., 9 parat. in MNS, parat. in MACN (2), IAD, FIML, BM, FMNH, UC, NHMB.

6 parat., 4 of them: "Piche Alhue / $1800 \mathrm{~m}$ Prov. Stgo. / 1, 8 Dic. 1969 / Coll.: L.E. Peña" printed; "FMNH, 1986 ; L.E. Peña coll. / Acc \# 17-422" printed; "Callyntra cantillana n. sp. / P. Vidal \& G. Flores Det. 2000" printed on white paper. The other two: "Chile Central / Cord. Costa $2000 \mathrm{mts}$ / Alto de los Gusanos / 6-9 Nov 1981 Peña” printed; all: "Paratypus" printed on red paper.

Note: The 4 parat. from Piche Alhue were sent by FMNH to one of us (GEF) in order to be deposited in MACN.

caraboides [Scotobius] Fairmaire 1905: 289. Mendoza.

Lectot. "Rep. Argentina / Prov. Mendoza / 1.1901 / C. Bruch" printed on white cardboard, date handwr.; "Typus" printed on pale green paper; "Scotobius / caraboides / Fairm. tipo" handwr. by Bruch, with a red frame; "Scotovius [sic] caraboides/ Fm n. sp." handwr. by Fairmaire, cut; "Lectotypus / Scotobius caraboides / Fairmaire, 1905 / Des. G. Flores 2006" printed on red paper. Ex BR.

Note: Flores (2007a: 424) designated lectot. 
cariosicollis [Psectrascelis] Fairmaire 1904: 64. Catamarca: Cerro Negro, $4000 \mathrm{~m}$.

Lectot. and 1 paralectot. Lectot. "Rep. Argentina / Prov. Catamarca / 4.I.1897/ C. Bruch" printed on white cardboard, date handwr.; "Typus" printed on pale green paper; "Psectrascelis / cariosicollis / Fairm - tipo" handwr. by Bruch, with a red frame; "Psectrascelis / cariosicollis Fm. n. sp." handwr. by Fairmaire; "Lectotypus/ Psectrascelis / cariosicollis / Fairmaire, 1904 / Des. G. Flores 2006" printed on red paper. Paralectot. "Rep. Argentina / Prov. Catamarca / 1900 / C. Bruch", printed on white cardboard; "Paralectotypus / Psectrascelis / cariosicollis / Fairmaire, 1904 / Des. G. Flores 2006" printed on red paper. One of us (AOB) had previously added to the other "Psectrascelis / cariosicollis / Fairmaire 1904 / Syntypus" handwr. on red cardboard. Ex BR.

Note: Flores (2007a: 424) designated lectot. and 1 paralectot.

chechoi [Physogaster] Peña 1995: 125, f. 14, 22. San Juan: Leoncito Valley 20.I.1995 leg. Peña \& Escobar, holot., 8 parat. in MACN; allot., 8 parat. in FMNH; 2 each in MNS, LP, MNHN, UC, PM, coll. J. Barriga.

Holot., 5 parat. "Valle Leoncito / San Juan Argentina / 20 Enero 1995 / Leg. L.E. Peña / J. Escobar" printed on white paper; on the holot. "Physogaster/ chechoi n. sp. / Holotypus [handwr.] / det. Luis E. Peña G. 95 [printed]" on white paper with a red frame; the other "Paratypus" printed and marked with red.

cicatricosus [Cardiogenius] Burmeister 1875: 469. [Uruguay:] Montevideo.

3 synt., the first one "Banda / Oriental" [= Uruguay] printed on green paper, the other two without locality label. One of us (AOB) added "Cardiogenus / cicatricosus / Burmeister 1875 / Syntypus" handwr. on red cardboard. Ex HB.

Notes: On the bottom of the drawer a label reads: "granulatus / Fairm. / cicatric. Br." handwr. by Burmeister. Cardiogenius cicatricosus Burmeister 1875 is a homonym of C. cicatricosus Solier 1836. Haag-Rutemberg (1876: 108) suggested C. cicatricosus Burmeister non Solier may be a synomym of $C$. granulatus Fairmaire 1873; the synonymy was accepted by Burmeister (1877: 68). Gebien (1910: 139) added C. variolosus Burmeister 1875 as another synonym of $C$. granulatus Fairmaire. concinna [Praocis] Burmeister 1875: 496-497. Córdoba.

Lectot. and 2 paralectot. "Cordova" printed on green paper, reverse white [on two], one paralectot. without label; "Lectotypus [on one] Paralectotypus [on two] / Praocis concinna/ Burmeister, 1875/ Des. G. Flores 2006" printed on red paper. One of us (AOB) had previously added "Praocis / concinna / Burmeister 1875 / Syntypus" handwr. on red cardboard. Ex HB.

Note: Considered by Kulzer (1958a: 93) as incertae sedis; in his monography of the Praocini he did not examine the type specimens. Flores (2007a: 418) designated lectot. and 2 paralectot. and placed it in Praocis (Postpraocis).

confluens [Nyctelia] Fairmaire 1905: 292. Tierra del Fuego.

Lectot. "Rep. Argentina / Gob. T'. d. Fuego / 190_/ C. Bruch" printed on white cardboard; "Typus" and "Foto" printed on pale green paper; "Nyctelia / confluens / Fair. tipo" handwr. by Bruch, with a red frame; "Nyctelia [cut, with remainings] /confluens Fm. n. sp." handwr. by Fairmaire; "Nyctelia / Westwoodi / Waterh." handwr. by Bruch on white paper; "Lectotypus / Nyctelia confluens / Fairmaire, 1905 / Des. G. Flores 2006" printed on red paper. Ex BR.

Notes: Put in synonymy of Nyctelia westwoodi Waterhouse 1841 (Gebien, 1937: 746; Kulzer 1963: 56). Flores (2007a: 421) designated lectot.

confusa [Scelidopsecta] Peña 1985b: 88-89, f. 3. Catamarca: El Arenal; San Juan: Agua Negra 3500 $\mathrm{m}$ leg. Roig; 1 parat. without locality label. Holot., 4 parat. in MACN; allot., 3 parat. in LP.

Holot. "El Arenal / Catamarca Argentina / 4-Oct. 1968 / Coll. L.E. Peña G. 1984” printed on white paper; "Scelidopsecta confusa / n.sp. ○" Holotype / det. L.E. Peña G. 1984" handwr. on white paper, with a red frame. 2 parat., one of them "R.A. San Juan / Paso Agua Negra 3500 m 22-I-1982. A. Roig” handwr. on white paper; "Scelidopsecta sp. [handwr.] / det.: L.E. Peña G. 1983 [printed]"; the other "Scelidopsecta / confusa n. sp. [handwr.] / det.: L.E. Peña G. 1984 [printed]" on white paper; both "Paratypus" printed on orange-red paper.

contracta [Asidelia] Fairmaire 1905: 296-297. Santa Cruz. 
Lectot. "Rep. Argentina / Gob. Santa Cruz / IV.1903 / C. Bruch" printed on white cardboard, date handwr.; "Typus" printed on pale green paper; "Asidelia / contracta / Fair. tipo" handwr. by Bruch, with a red frame; "Asidelia / contracta / Fm. n.g. n.sp." handwr. by Fairmaire, cut.; "Lectotypus / Asidelia contracta / Fairmaire, 1905 / Des. G. Flores 2006" printed on red paper. Ex BR.

Note: Flores (2007a: 420-421) designated lectot.

cordobensis [Epipedonota] Flores \& Vidal 2001: 8, 31-32, f. 19, 30, 31, 35. Córdoba: Cuchi Corral, 1 parat., and Córdoba: Los Cocos, 1 parat. in MACN. Holot., male Córdoba: Capilla del Monte, in IAD; Córdoba: Charbonnier to Copacabana, allot. female in FIML; Sierras de Córdoba, 1 parat. in FIML; Córdoba Prov., 2 parat. in Univ. Córdoba.

2 parat., one of them "Los Cocos" the other one "Cuchi Corral" handwr.; both "Paratypus" printed on red paper; "Epipedonota / cordobensis sp. n. / Det. G. Flores - P. Vidal 2000" printed on white paper.

coriaria [Psectrascelis] Fairmaire 1905: 297. Catamarca, sent by Bruch.

Lectot. "Rep. Argentina / Prov. Catamarca / 190 / C. Bruch" printed on white cardboard, "Typus" and "Foto" printed on pale green paper; "Psectrascelis / coriaria / Fm n. sp." handwr. by Fairmaire; "M5" handwr. on pink paper; "Psectrascelis / coriaria / Fairm. tipo" handwr. by Bruch, with a red frame; "Psectrascelis / coriaria Fair. / Syntypus / det.: L.E. Peña G. 1983” handwr. on white paper with a red frame; "Lectotypus / Psectrascelis/ coriaria / Fairmaire, 1905 / Des. G. Flores 2006" handwr. on red paper. Ex BR.

Note: Flores (2007a: 424) designated lectot.

coscaroni [Pilobalia] Peña 1973: 169, f. 2, 7, 11, 15, pl. 1: E. Jujuy: río Cincel 3500 m, 10.II.1970; Cienaguillas 3200-3300 m 5.II.1970; 6 parat. in MACN; holot., allot., 804 parat. in LP; other parat. in FIML, MNS, MLP and several other institutions.

6 parat. "Río Cincel / 3500 m. Jujuy / Argentina / 10-Febr. 1970 / Coll.: L.E. Peña" printed on white paper; "Paratipo" printed on red paper; "Pilobalia / coscaroni nov. sp. / det.: L.E. Peña 1971 " printed on white paper. costatus [Thylacoderes] Flores 2000b: 81, 85-87, f. 4, 12, 21-23. Entre Ríos: El Palmar, 1 parat. in MACN. Holot., male, allot. fem., 9 parat. IAD; further parat. in several institutions.

1 parat. "Argentina / Entre Ríos / El Palmar / Sergio Roig" printed on white paper; "Paratypus" printed on red paper; "Thylacoderes / costatus n. sp. / Det. G. Flores 2000" printed on white paper.

crassecostata [Nyctelia] Fairmaire 1905: 295296. Río Negro.

Lectot. "Rep. Argentina / Gob. Río Negro / 190_ / C. Bruch" printed on white cardboard; "Typus" and "Foto" printed on pale green paper; "Nyctelia / crassecostata / Fair. tip." handwr. by Bruch, with a red frame; "Nyctelia [cut, with remainings] / crassecostata Fm. n. sp." handwr. by Fairmaire; "Lectotypus/ Nyctelia crassecostata / Fairmaire, 1905 / Des. G. Flores 2006” printed on red paper. Ex BR.

Note: Flores (2007a: 422) designated lectot.

crenata [Lepidocnemeplatia] Viana 1960: 260264, pl. i: 1-5. Córdoba: Calamuchita: El Sauce leg. Viana II.1953, holot., male, allot. fem., 9 parat. in MACN sub 53901; 1 parat. Catamarca: Belén: La Ciénaga leg. Weiser \& Wolters XII.1925 ex coll. Bruch sub 53902; other parat. in MLP.

Holot., male, allot., fem., 8 parat. glued to cards, each on a pin "Córdoba - Argentina / Dep. de Calamuchita / 'El Sauce' - Manuel J. Viana" printed on white cardboard, date deleted; " 53901 " handwr.; "Lepidocnemeplatia / crenata / Viana / Holotipo $\sigma^{7}$ " on holot., handwr. on red cardboard; the allot. similar but "Alotipo $ᄋ$ ", the parat. similar but "Paratipo" on orange-yellow cardboard, all with "Museo Argentino de Ciencias Naturales" printed. 1 parat. glued to a card, "La Ciénaga (Belén) / Catamarca XII-1925 / Weiser Wolters leg." printed on white paper, date handwr.; "53902" handwr.; "Lepidocnemeplatia / crenata / Viana / Paratipo" handwr. on orange-yellow cardboard.

Note: One parat. from Córdoba: Calamuchita was sent as a matter of exchange to L. Peña in IX.1991.

cribricollis [Scotobius] Fairmaire 1905: 289. Salta.

Lectot. "Rep. Argentina / Prov. Salta / III.1897 / C. Bruch" printed on white cardboard; "Typus" 
printed on pale green paper; "Scotobius / cribricollis / Fairm. tipo" handwr. by Bruch, with a red frame; "Scotobius cribricollis / Fm n. sp." handwr. by Fairmaire, cut; "Lectotypus / Scotobius / cribricollis / Fairmaire, 1905 / Des. G. Flores 2005" handwr. on red paper. Ex BR.

Notes: Kulzer (1955: 441) synonymized Scotobius cribricollis with $S$. planatus Erichson examining two specimens of $S$. cribricollis from Salta, one in the MNHN and the other one the MF. Howewer, Kulzer (1955: 441) did not examine and did not mention the location of the type specimen(s) of Scotobius cribricollis. Flores (2007a: 424-425) designated lectot.

depressipennis [Lystronychus] Pic 1921: 13. Argentina.

2 synt., one of them glued to a card "Rep. Argentina / Pr. Santiago d. Estero / 190_/ C. Bruch" printed on white cardboard; "Typus" printed on pale green paper; "Lystronychus / depressipennis / Pic" handwr. by Bruch, with a red frame; "Lystronychus / depressipennis Pic" handwr. by Pic?. The other one pinned, "Rep. Argentina / Prov. Catamarca / II.1910 / C. Bruch" printed on white cardboard, date handwr. One of us (AOB) added "Lystronychus depressipennis / Pic 1921 / Syntypus?" handwr. on red cardboard. Ex BR.

Note: The $2^{\text {nd }}$ spec. is perhaps not a synt.

despecta [Camaria] Gebien 1919: 105. Brasil: Rio de Janeiro, 1 males, 3 fem. in coll. Gebien.

1 synt.? "Rep. Brasil / IX.1901 / C. Bruch" printed on hite cardboard, date handwr.; "Cotypus" printed on pale green paper; "Camaria / despecta / Geb. O" " handwr. by Bruch, with a red frame; "Camaria despecta G [handwr.] / H. Gebien det. [printed]", cut. Ex BR.

Note: The type condition of the spec. is dubious. Gebien stated that the types are in his collection, and did not mention any in the Bruch coll.

digitatus [Orthonychius] Gebien 1926: 84-85, pl. 2: f. 1, 2. Catamarca: Puerta Corral Quemado 2030.IV.1924 Weiser leg., many specimens sent by Bruch.

2 synt. glued to cards (one on venter, one on dorsum), on 1 pin, "Corral Quemado / Catam. Weiser" handwr. by Bruch; "Typus" and "Foto" printed on pale green paper; "Orthonychius / digitatus / Gebien" handwr. by Bruch, with a red frame. Ex BR.
Notes: Gebien illustrated the species using the photos (dorsal and ventral views) taken by Bruch $(f .1,2)$. There are seven further spec. with similar labels, probably not intended to be types. Peña (letter of 29.VIII.1991) says the type should be in MF.

discoidalis [Nyctelia] Fairmaire 1905: 292. Chubut.

Lectot. "Rep. Argentina / Gob. Chubut / II.1895 / C. Bruch" printed on white cardboard, date handwr.; "Typus" and "Foto" printed on pale green paper; "Nyctelia / discoidalis / Fair. tipo" handwr. by Bruch, with a red frame; "Nyctelia [cut, with remainings] / discoidalis Fm n. sp." handwr. by Fairmaire; "Lectotypus / Nyctelia discoidalis / Fairmaire, 1905 / Des. G. Flores 2006" printed on red paper. Ex BR.

Notes: Kulzer (1963: 64) stated that the type was unknown to him. Flores (2007a: 422) designated lectot.

dorsata [Nyctelia] Fairmaire 1905: 295. Chubut. Lectot. "Rep. Argentina / Gob. Chubut / 190 / C. Bruch" printed on white cardboard; "Typus" printed on pale green paper; "Nyctelia / dorsata / Fair. tipo" handwr. by Bruch, with a red frame; "N. dorsata Fm. n. sp." handwr. by Fairmaire, cut, "Fm." hardly readable; "Lectotypus / Nyctelia dorsata / Fairmaire, 1905 / Des. G. Flores 2006" printed on red paper. Ex BR.

Notes: Kulzer (1963: 35-36) stated the type was unknown to him. Flores (2007a: 422) designated lectot.

elegans [Mitragenius] Peña 1986a: 52-53, f. 11. Neuquén: Río Quillén 31.I.1961, holot., male in MACN, allot. and parat. in LP.

Holot. "R. Quillen, Neuquén / 31-I-1961 Arg. [handwr.] / Col. H.J. Molinari [printed]" on white paper; "Leg. Monné - A. Mesa" handwr.; "Mitragenius / breviangulus / Klzr. 1954" handwr.; "Mitragenius elegans / n. sp. / Holotypus $\sigma^{7}$ / det. L.E. Peña G. 1986" handwr. on white paper with a red frame.

Note: transferred to Patagonogenius by Flores (1999: 395, f. 37, 46).

escobari [Pilobalia] Peña 1973: 173-174, f. 4, 17, pl. 1: I. Jujuy: Cienaguillas 3200 m, N of Pozuelos pond, 1 parat. in MACN. Holot., allot. 1 parat. in LP, other parat. in MNS, MLP, and other institutions. 
1 parat. "Argentina / Cienaguillas / Jujuy 3200 m/ 8-Nov. 1968/ Coll.: L.E. Peña" printed on white paper; "Paratypus" printed on orange-red paper; "Pilobalia / escobari / nov. sp. / det.: L.E. Peña 1971 " printed on white paper.

exasperata [Nyctelia] Fairmaire 1905: 292-293. Buenos Aires.

Lectot. and 1 paralectot. "Rep. Argentina / Prov. Buenos Aires / 189_ [on lectot.], 190_ [on paralectot.] / C. Bruch" printed on white cardboard; "Typus" printed on pale green paper. The lectot. "Nyctelia / exasperata / Fair. tipo" handwr. by Bruch, with a red frame; "Nyctelia [cut, with remainings] / exasperata Fm. n. sp." handwr. by Fairmaire; "Lectotypus [on one] Paralectotypus [on the other] / Nyctelia exasperata / Fairmaire, 1905 / Des. G. Flores 2006” printed on red paper. The paralectot. "Foto" printed on pale green paper; one of us (AOB) had previously added "Nyctelia / exasperata / Fairmaire 1905 / Syntypus" handwr. on red cardboard. Ex BR.

Note: Flores (2007a: 423) designated lectot. and 1 paralectot.

exigua [Allecula] Borchmann 1930b: 89-90, pl. iii: 1. Jujuy: Volcán 23.I.1923 leg. Wagner; Tucumán: Trancas, leg. Weiser; Santiago del Estero, leg. Wagner.

3 synt. glued on cards, on 3 pins, two of them "Stgo Estero / E. Wagner" handwr. by Bruch; "Typus" printed on pale green paper; "Allecula / exigua / Borchm." handwr. by Bruch, with a red frame; "Allecula exigua m." handwr. by Borchmann? cut. The $3^{\text {d }}$ one "El Volcán / Jujuy 23.I.21" handwr. by Bruch; "Fototipo" handwr. by Bruch on pale green paper, the remaining labels similar to the above, but without red frame. Ex BR.

fimbriata [Praocis] Burmeister 1875: 496. Patagonia: Río Santa Cruz.

Lectot. without labels and 1 paralectot., "Patagonia"; "Lectotypus [on one] Paralectotypus [on the other] / Praocis fimbriata/ Burmeister, 1875/ Des. G. Flores 2006] printed on red paper. The paralectot. with additional label: "Praocis / striolicollis / Fairmaire, 1883 / Det. G. Flores 2006" handwr. on white paper. One of us (AOB) had previously added to both "Praocis / fimbriata / Burmeister 1875 / Syntypus", handwr. on red cardboard. Ex HB.
Notes: There are two further spec., labelled "Carm. Patag." and "Chubut" respectivelly, which are probably not syntypes. In MLP there is another paralectot. labelled "Typus", "S. Cruz / Patag.", "Praocis / fimbriata / Burm. (handwritten by Berg)" and "Paralectotypus / Praocis fimbriata / Burmeister, 1875 / Des. G. Flores 2006”. Kulzer (1958a: 62) stated the type was unknown to him. Currently in Praocis (Hemipraocis). Flores (2007a: 420) designated lectot. and 2 paralectot.

foersteri [Omopheres] Freude 1967: 211-212. La Rioja: Patquía X.1957, holot., male, allot., fem. and many 'paratypoids' in coll. Ardoin, Arcachon, France [now in MNHN, J. Ferrer, pers. comm.]. Other 'paratypoids' Río Negro: Lamarque, ChoeleChoel, Villa Regina, Coronel Gómez, and Cipolletti; Buenos Aires: Río Colorado; San Juan: Desamparados; Santiago del Estero: Río Hondo; La Rioja, city; Catamarca: Chumbicha; in several collections.

1 parat. "Argentina / Prov. La Rioja [printed]/ Patquía / X.57 [handwr.]" on white paper; "Om. / foersteri m. [handwr.] / det. H. Freude 1963 [printed]" on white paper; "Paratypoid" printed on red paper. Ex ERT.

formicophilus [Poecilocrypticus] Gebien 1928: 122-123. Brasil: Rio Grande do Sul: Leopoldo, leg. Heyer, with Prenolepis fulva [Hym., Formicidae], in coll. Gebien; Prov. Buenos Aires 30.VI.1903, Bruch; Mendoza.

1 synt.? glued to a card "Rep. Argentina / Prov. Buenos Aires / 189_/ C. Bruch" printed on white cardboard; "Typus" printed on pale green paper; "Poecilocrypticus / formicophilus / Geb." handwr. by Bruch, with a red frame. Ex BR.

Notes: The spec. lacks both date and identification label handwr. by Gebien, suggesting it is not a syntype. Steiner (1982: 233-238) examined types in MF, including a 'cotype' from "B. Aires Mendoza" [an extended range?]. Gebien did not mention how many specimens he used to describe this species, but he figured the variations observed in at least three different elytra (Gebien 1928: f. 8) and stated three typical localities: [São] Leopoldo (Brasil, Rio Grande do Sul), Heyer leg., labelled "Type"; Mendoza (Argentina), labelled "Cotype", and "Buenos Aires". Steiner (1982) studied the four specimens of the Gebien coll. (at that time in the Munich Mus., now in NHMB). Then the specimen in MACN, from Buenos Aires, 
seems to have been studied by Gebien, and to pertain to the type-series (G.E. Flores).

gentilii [Mitragenius] Peña 1986a: 53-55. f. 9. Neuquén: Marucho 8.XII.1966, holot., male in MACN; Chubut: Cerro Negro, allot., fem. in LP.

Holot., with genitalia glued to a pointed card "Cerro Negro / Chubut / Fortuna" handwr. by Bruch; "Mitragenius / gentilii / nov. sp. / Holotypus $\sigma^{7}$ [handwr.] / det. L.E. Peña G. 1986 [printed]" on white paper with a red frame. Ex BR.

Note: Transferred to Patagonogenius by Flores (1999: 391-392, f. 35, 41, 42, 460).

geometrica [Nyctelia] Fairmaire 1905: 292. Chubut (Patagonia).

Lectot. "Rep. Argentina / Gob. Chubut / 3.1900 / C. Bruch" printed on white cardboard, date handwr.; "Typus" printed on pale green paper; "Nyctelia / geometrica / Fair. tip." handwr. by Bruch on white paper with a red frame; "Nyctelia [cut, with remainings]/ geometrica Fm. n. sp." handwr. by Fairmaire; "Lectotypus / Nyctelia geometrica / Fairmaire, 1905 / Des. G. Flores 2006" printed on red paper. Ex BR.

Note: Flores (2007a: 422) designated lectot.

glaber [Physogaster] Peña 1995: 123, f. 16, 20. Jujuy: Tilcara 7.II.1970 leg Peña, holot., male, 6 parat. in MACN; allot. fem., 9 parat. FMNH; 2 parat. each in: MNS, MNHN, UC, PM, LP, coll. J. Barriga.

Holot., 6 parat. "N. Tilcara / 2900 m. Jujuy / Argentina / 7-Febr-1970 / Coll. L.E. Peña" printed on white paper; "Physogaster / glaber n.sp. [and $\sigma^{7}$ on the holot.] / Holotypus [Paratypus on the other ones] / det.: L.E. Peña G. 95” printed on white paper.

granulata [Psectrascelis] Molinari 1968: 133134, f. 4. Jujuy: Pucapampa to Santa Catalina, 2 parat. in MACN ex coll. Bruch. Holot., male, allot. fem., 25 parat. in MLP, 14 parat. in coll. Molinari [now in IAD].

2 parat. "Rep. Argentina / Prov. Jujuy / 29.XI.1909/ C. Bruch" printed on white cardboard, date handwr.; "Pucapampa a Sta. Catalina" handwr. by Bruch. 2 parat. "Santa Catalina (Jujuy) 25.I.59 / Torres - Dadone col.” printed on white paper; all four: "Paratypus" printed on orange yellow cardboard; "Psectrascelis (Cerostena) granulata n. sp. [handwr.] / det. H.J. Molinari 1968 [printed]" on white paper.

Notes: Only 6 parat. of this species are kept in the Molinari coll. (now in IAD); presumably the remaining 8, said to be therein, remained in $\mathbf{L P}$, and should be now in FMNH. Synonymized with P. strigosicollis (Fairmaire) by Peña (1985a: 42).

granulosa [Scelidopsecta] Peña 1985b: 86-88, f. 1. San Juan: Campo Leoncito 21.I.1982 A. Roig leg., holot. in MACN, allot. in LP. 1 parat. Mendoza, "7632"; "lobata" det. Molinari, in MACN.

Holot., with genitalia glued to a pointed card "R.A. San Juan / Campo El Leoncito / 15 Km Sur Tocota / 21.I.1982. A. Roig" handwr. on white paper; 1 parat., with genitalia glued to a pointed card, "7632" handwr.; "Mendoza" handwr.; "Scelidopsecta / lobata Burm. 1875 [handwr.] / det. H.J. Molinari 1971 [printed]" on white paper. Both "Scelidopsecta / granulosa / n. sp. O" / Holotype [only the holot., handwr.] / det.: L.E. Peña G. 1984 [printed]" on white paper, on the holot. with a red frame, on the parat. "Paratypus" printed on orange red cardboard.

hirsutus [Cardiogenius] Burmeister 1875: 469. [Uruguay:] Montevideo.

4 synt., 2 of them "Banda / Orient." [ = Uruguay], the other 2 without labels. A label on the bottom of the drawer reads "crinifer / Fairm. / hirsut. Br." handwr. by Burmeister. One of us (AOB) added "Cardiogenius / hirsutus / Burmeister 1875 / Syntypus" handwr. on red cardboard. Ex HB.

Note: Synonymized with C. crinifer Fairmaire 1873 by Haag-Rutemberg (1876: 108) and Burmeister (1877: 68).

ignaciosus [Lystronychus] Pic 1930c: 18. Argentina. [Probably more than one spec., as the measurements are given as a range]

1 synt. glued to a card "Argentina / Iguazú / A. Breyer / X.1928 [or 1926?]" printed; "Cotypus" handwr. by Bruch on pale green paper; "Lystronychus / ignaciosus / Pic" handwr. by Bruch, with remainings of a black frame; "Lystronychus / ignaciosus Pic" handwr. by Pic?, cut. Ex BR.

impressipennis [Lystronychus] Borchmann 1912: 388-389. Córdoba, 1 male; Catamarca 1 fem. 17.I.1910, in BR. 
1 synt. "Rep. Argentina / Prov. Catamarca / 17.I.1910 / C. Bruch" printed on white cardboard, date handwr.; "Typus" printed on pale green paper; "Lystronychus / impressipennis / Borchm." handwr. by Bruch, with a red frame; "Lystronychus / impressipennis" handwr. by Borchmann?, cut, with remainings of a black frame. Ex BR.

inermis [Praocis] Burmeister 1875: 497. Patagonia, brought by Berg.

Lectot. "Carm. / Patag." printed on green paper; "Lectotypus / Praocis inermis / Burmeister, 1875/ Des. G. Flores 2006” printed on red paper. One of us (AOB) had previously added "Praocis / inermis / Burmeister 1875 / Typus" handwr. on red cardboard. Ex HB.

Notes: Currently in Praocis (Hemipraocis). Flores (2007a: 414) designated lectot. and considered $P$. compacta Fairmaire 1883 as synonym.

infernalis [Entomoderes] Burmeister 1875: 483484. Catamarca.

Holot. "Catamarca" printed on green paper, reverse white; "727" printed on white paper. One of us (AOB) added "Holotypus" printed, and "Entomoderes / infernalis / Burmeister 1875" handwr., both on red cardboard. Ex HB.

infravestita [Cerostena] Fairmaire 1905: 297298. Catamarca, sent by Bruch.

Lectot. "Rep. Argentina/ Prov. Catamarca/ 190 / C. Bruch" printed on white cardboard; "Typus" printed on pale green paper; "Cerostema / infravestita / Fairm. tipo" handwr. by Bruch on white paper with a red frame; "Cerostenna / infravestita Fm. n. sp." handwr. by Fairmaire on grayish white paper; "Psectrascelis / infravestita Fair. / (Syntypus) [handwr.] / det.: L.E. Peña G. 1983" printed on white paper with a red frame; "Lectotypus/ Cerostena / infravestita / Fairmaire, 1905 / Det. G. Flores 2006" printed on red paper. Ex BR.

Notes: Recorded as Psectrascelis infravestita by Gebien (1910: 146). Cerostena was considered as subgenus of Psectrascelis by Gebien (1937) and Kulzer (1954). Peña (1985a) synonymized Cerostena with Psectrascelis and designated lectot. (Peña 1985a: 46). Because Peña made a mistake adding a label of syntypus, one of us (GEF) added the label of identification of lectot.

interandina [Epipedonota] Flores \& Vidal 2001: 8, 25-27, f. 36. Jujuy: Abra Pampa, holot., male in
FIML; Chile: Antofagasta: Helada Pond, allot., fem. in MNS; parat. in several coll. including MACN.

6 parat., 1 of them "Rep. Argentina / Prov. Salta / 5.IV.1923 / C. Bruch" printed on white cardboard, date handwr.; "San Antonio / de los Cobres / 3900 m. Weiser" handwr. by Bruch; "Epipedonota / sublineata / Berg" handwr. by Bruch, with a green frame; 3 of them "R.A. Jujuy / Dto Cochinoca / Abra Pampa / E. Maury" printed on white paper; 2 of them "Lever / E. Toconao / Prov. Antofagasta" and "22-marzo-1969 / Coll. Soza" printed on white paper. All six with "Paratypus" printed on red cardboard; "Epipedonota / interandina sp. n. / Det. P. Vidal G. Flores 2000" printed on white paper.

intercostata [Epipedonota] Berg 1901: 269-270. Salta: Cachi Pampa; Tucumán; 4 spec. in MACN (3 from Salta), and 1 in $\mathbf{C B}$ (Salta).

Lectot., 3 paralectot., 2 of them " 4227 " handwr.; "Cachi / Cachipampa. Pr. Salta"; (on one "intercostata / Berg" handwr. on white paper with a red marginal stripe); and 1 "Salta", all 3 handwritten on green paper; the remaining "Tucu- / man" printed on green paper; all 4 "Typus" printed with red ink on white paper, with a red frame; "Epipedonota intercostata / Berg / Lectotypus [on $1^{\text {st }}$ one, Paralectotypus on the other three] / G. Flores \& P. Vidal Des. 1999" printed on red paper.

Notes: Lectot. and paralectot. designated by Flores \& Vidal (2001: 25). In MLP there is another paralectot. labelled "Typus" and "Salta", probably the one of CB which was not found in MACN. Considered as a subspecies of $E$. monilis by Gebien (1937: 749) and Kulzer (1954: 161); upgraded to species rank by Flores \& Vidal 2001: 23-25.

intermedium [Oligocara nitidum subsp.] Peña \& Barría 1975: 43-44, pl. 1: 2, pl. 2: 4, pl. 4. Chile: El Coigo, cord. Curicó VII.1964, holot, male in LP; several localities in prov. Talca, Nuble, Curicó, etc., allot., female and 18 parat. in $\mathbf{L P}$, other parat. in several institutions.

1 parat., with genitalia glued to a pointed card, "El Coigual / Cord. Curico / IV.55. Peña" handwr. on white paper; "Paratypus" printed on red paper; "Oligocara / nitidum Sol. [handwr.] / det. H. Kulzer 1958 [printed]" on white paper; "Oligocara / nitidum / intermedia / nov. ssp. / Det. L. Peña 1975 " printed on white paper. 
izquierdoi [Psectrascelis] Peña 1985a: 28-30, f. 6, 14, pl. 2. Chile: Antofagasta: Chépica; salar Puntas Negras; La Ola; Bardas Negras; holot., allot., 44 parat. in LP; other parat. in several institutions.

1 parat. "Cta. Bardas Negras / E. Catalina: Antof. / 30.XI.1975 Chile / L.E. Peña G.” handwr. on white paper; "Paratypus" printed on orangered paper; "Psectrascelis / izquierdoi / n. sp./ det.: L.E. Peña 1983" printed on white paper.

jujuyensis [Epipedonota] Flores \& Vidal 2001: 8, 19-21, f. 16, 34. Jujuy, ex BR, holot., male, allot., fem., 1 parat. in MACN, other parat. from Jujuy: Tilcara; Quebrada de Humahuaca; Maimará, Purmamarca; Huacalera; Uquía, in MACN, IAD, FIML, FMNH.

Holot., male, allot., fem., 1 parat. "Rep. Argentina / Prov. Jujuy / 29.XII.1919 / C. Bruch" printed on white cardboard; "Puca-Pampa / Sta. Catalina" handwr. by Bruch; "Epipedonota / jujuyensis sp. n. / Holotypus male [on the others: "Allotypus female", "Paratypus"] / G. Flores - P. Vidal 2000" printed on red paper. 2 parat. "Patagonia" handwr. on green paper with a black frame, reverse white; "Epipedonota / monilis / angustata / Burm., 1875 [handwr.] / det. H.J. Molinari 1971 [printed]" on white paper. 4 parat. "Jujuy" handwr. on green paper with a black frame, reverse white, 3 of them "7879" handwr.; 2 parat. " 26764 ", “25765” handwr. [after register book: Jujuy: Sierra de Zenta, E. Budin leg.]; 1 parat. "Argentina / Misiones" printed; 2 parat. "R.A. Jujuy / Quebrada de / Humahuaca / I.1941 Haedo" printed on white paper; 1 parat. "R.A. Jujuy / Dto. Tilcara / Tilcara / Casanova - Gatto" printed on white paper. 2 parat. "Jujuy / Tilcara IV.983 / P. Goloboff" handwr. on white paper, one of them with genitalia in a plastic microvial.

laterufa [Lobopoda] Pic 1930b: 45. Santiago del Estero: Vilelas, leg. Konstantinoff, in BR.

Holot. glued to a card, "Vilelas / Konstantinoff" handwr. by Bruch; "Typus" handwr. by Bruch on pale green paper; "Lobopoda / laterufa / Pic" handwr. by Bruch; "Lobopoda / laterufa n.sp." handwr. by Pic?, cut. Ex BR.

laticauda [Nyctelia] Burmeister 1877: 70-71. Río Negro: Nahuel Huapi.

Lectot. "Nuah / Hapi [sic]" handwr. on green paper; "Lectotypus / Nyctelia laticauda / Burmeister, 1877 / Des. G. Flores 2006” printed on red paper. One of us (AOB) had previously added "Nyctelia / laticauda / Burmeister 1877 / Typus" handwr. on red cardboard. Ex HB.

Note: Flores (2007a: 414-415, f. 1) designated lectot. and considered $N$. planicauda Fairmaire 1905 as synonym.

latithorax [Psectrascelis] Peña 1985a: 44-45, pl. 5. Chubut: Comodoro Rivadavia, holot. in MACN.

Holot. "11630" handwr.; "Comodoro / Rivadavia" handwr. on green paper, reverse white; "Psectrascelis (s. str.) nitida / Klzr. 1954 [handwr.] / det. H.J. Molinari 1971 [printed]" on white paper; "Psectrascelis / latithorax / n.sp. Holotypus / det. L.E. Peña G. 1983" handwr. on white paper with a red frame.

lobatus [Entomoderes] Burmeister 1875: 486487. [Mendoza:] sierra de Aspallata [sic, pro Uspallata]; S. Juan: sierra de Tontal.

2 synt., one of them "Sierra / d. Mendoz." printed on green paper; "726" printed; "Cotypus" printed on red paper; "Scelidopsecta / lobata / Burm. [handwr.] / det.: L.E. Peña G. 1984 [printed]" on white paper. One of us (AOB) added to the other "Entomoderes / lobatus / Burmeister 1875 / Syntypus" handwr. on red cardboard. Ex HB.

Notes: Recorded under Psectrascelis (Cerostena) by Gebien (1937: 751), and under Psectrascelis by Blackwelder (1945: 519); designated type species of Scelidopsecta by Kulzer (1954: 204-206, 265).

longipilis [Physogaster] Peña 1995: 124-125, f. 13, 21. Mendoza: Uspallata 31.III.1967 leg. Peña \& Barría, holot., 6 parat. in MACN; allot., 55 parat. in FMNH; 4 parat. each in MNS, LP [now in coll. Pedro Vidal, Chile], MNHN, PM, UC; 49 parat. in coll. J. Barriga.

Holot., 6 parat. "Uspallata / 31-marzo-1967", "Argentina / Mendoza" and "Coll. L.E. Peña/ y G. Barría" all three printed on white paper; "Physogaster / longipilis nov. sp. / Holotypo [handwr. on one, "Paratypo" on the remaining six] / det. Luis E. Peña G. 95 [printed]" on white paper with a red frame, one of them "Physogaster / n. sp. [handwr.] / det. H. Kulzer 1968 [printed]" on white paper. 2 parat. "Uspallata / Mendoza / Argentina / 15-Abr-1987 leg. E. Barriga" printed on white paper; "Physogaster / longipilis n. sp. / Paratipo / det.: L.E. Peña G. 1995” printed on white paper. 
magellanicum [Patagonopraocis] Flores \& Chani Posse 2005: 578-579, f. 2-3, 8-9, 12, 14, 17. Holot., allot. in MNS: Chile: Magallanes, Punta Espora (Tierra del Fuego), 1977 Col. J. Petersen; 42 parat. in FMNH, IAD, MNS, NHMB, FIML, 2 in MACN and in other institutions, same locality of holotype.

2 parat. male and female "Punta Espora/Magallanes (Chile)/ 1977/ Leg. Lanfranco" printed on white paper; "Paratypus" printed on red card; "Patagonopraocis / magellanicum n. sp. / Det. G. Flores \&/ M. Chani-Posse 2005" printed on white paper.

maximus [Psectrascelis] Peña 1986b: 59-60, f. 3. Chubut: Arroyito 325 m, 5.III.1973 leg. Gentili, holot., male in MACN; Neuquen: Coyunco, Cerro Mesa 800 m, 14.X.1971 leg. Gentili, allot., fem. in LP.

Holot., male "Arroyito 325 m.s.n.m. / Neuquen Arg. / 15-III-73 Leg. M. Gentili” photogr. from typed; "Psectrascelis / (Cerostena) grandis / Kulzer, 1954 [handwr.] / det. H.J. Molinari 1974 [printed]" on white paper; "Psectrascelis / maximus n. sp. / Holotypus O / det.: L.E. Peña G. 1986" handwr. on white paper with a red frame.

melcheri [Gyriosomus] Kulzer 1959: 545-546, pl. 12: 5. Chile: Coquimbo: Puerto Oscuro 6.XI.1957 leg. Peña, many spec.; holot., allot., parat. in LP; parat in MF.

1 parat. "Pto. Oscuro. Coquimbo / 6-Nov.-1957 / Coll.: L.E. Peña" printed on white paper; "Paratypus" printed on red paper; "Gyriosomus / melcheri Klz." handwr. on white paper.

mendocina [Epipedonota] Flores \& Vidal 2001: 9, 41-42, f. 9, 23, 35. Mendoza: Tupungato: pampa de La Carrera, holot., male, allot., fem., 6 parat. in IAD; other parat. in MACN, FMNH, MLP, FIML, MNS, Mus. Budapest, NHMB; 2 parat. Mendoza: Luján in IAD; 4 parat. Mendoza: Cerro La Plata in BM and NHMB.

2 parat. "Mendoza Tupungato / Pampa La Carrera / 12/X/985 S. Roig" printed on white paper; "Paratypus" printed on red paper; "Epipedonota / mendocina sp. n. / Det. G. Flores - P. Vidal 2000" printed on white paper.

microdera [Epipedonota] Burmeister 1875: 479. Pampa Occidental, between Desaguadero river and San Luis.

Lectot. "Pampa / occid." printed on green paper, "732" printed, inverted; "Epipedonota microdera / Burmeister / Lectotypus male / G. Flores \& P. Vidal Des. 1999" printed on red paper. One of us (AOB) had previously added "Epipedonota / microdera / Burmeister 1875 / Typus" handwr. on red cardboard. Ex HB.

Notes: Lectot. and paralect. designated by Flores \& Vidal (2001: 33) and synonymized with E. angusta Burmeister 1875 by Flores \& Vidal (2001: 32-33). Pampa occidental is a vague, old reference for the area including western La Pampa, southern San Luis and the southern half of Mendoza Provinces.

microplicatissima [Epipedonota] Flores \& Vidal 2001: 8, 28-29, f. 35. San Luis: Pringles: Río Grande pond, holot., male in MACN; San Luis (city), allot., fem. 1 parat. in MACN; S. Luis: Pedernera: El Morro, 1 parat. in IAD; S. Luis: Salto Moneda, 3 parat., in MLP, FIML, and Univ. S. Luis; San Luis: La Carolina, 3 parat., 2 of them in MACN, 1 in coll. Vidal.

Holot., male, with genitalia in a plastic microvial, "R.A. San Luis / Dto. Cnel. Pringles / Embalse Río Grande / 7.X.98 - M. García” printed on white paper; allot., 1 parat. "R.A. San Luis / San Luis / (MACN)" printed on white paper. 2 parat. "La Carolina / S. Luis" handwr., ex coll. Stevenin. All: "Epipedonota / microplicatissima sp. n. / G. Flores - P. Vidal 2000", printed on red paper, the allot. with "Allotypus", the parat. with "Paratypus" printed on red paper.

minor [Patagonopraocis] Flores \& Chani Posse 2005: 580, f. $4-5,10-11,15,18$. Holot. male in FIML: Chubut: $20 \mathrm{~km}$ W Alto Río Senguer, 5.II.1980, Willink-Fidalgo-Claps-Domínguez, 2 parat. males in IAD, MACN same locality of holotype; allot. female in IAD and 1 parat. female in FMNH, Santa Cruz: $35 \mathrm{~km}$ W Gobernador Gregores, 9.I.2005, G. Flores-S. Roig.

1 parat. male "Argentina, Chubut/ Dto. Río Senguer $693 \mathrm{~m} / 20 \mathrm{~km}$ W Alto Río Senguer/ 7.I.2005 G. Flores-S. Roig" and " $45^{\circ} 04.20^{\prime}$ S, $71^{\circ}$ 01.39' W" printed on white paper; "Paratypus" printed on red card; "Patagonopraocis / minor n. sp. / Det. G. Flores \&/ M. Chani-Posse 2005" printed on white paper.

modestus [Gyriosomus] Kulzer 1959: 544-545. Chile: Los Vilos [sic, pro Las Villas] holot., allot., 1 parat. ex coll. Gebien in MF. Chile: Coquimbo: Huentalauquen 6.XI.1957 leg. Peña, 260 parat. 
1 parat. "Huentalauquen / Coquimbo 6-Nov1957 / Coll.: L.E. Peña” printed on white paper; "Paratypus" printed on red paper; "Gyriosomus / modestus, Klz." handwr. on white paper.

monticola [Mitragenius] Berg 1889: 128-129. Córdoba, not rare.

1 (sole?) synt. "Typus" printed with red ink on white paper with a red frame; "Cordoba" handwr. on green paper; "Mitragenius / monticola / Berg 1889" handwr. by Berg on white paper tinged with green, with a red frame; " 210 " handwr. with red ink on white paper; "Mitrage-nius / dejeani / Solier 1836 [handwr.] / det. H.J. Molinari 1971 [printed]" on white paper; "Mitragenius / monticola / Burm., Typus [handwr.] / det. L.E. Peña 1986 [printed]" on white paper. One of us (AOB) added "Mitragenius / monticola / Berg 1889 / Typus" handwr. on red cardboard. Ex HB.

Notes: Synonymized with Mitragenius dejeanii Solier 1836 by Gebien (1937: 752) along with pictus Lacordaire 1830, desertorum Lacordaire 1830, and servus Waterhouse 1844. M. desertorum, servus and pictus are nomina nuda from Lacordaire (1830). M. servus was synonymized with dejeanii by Fairmaire (1876); pictus was synonymized with desertorum by Gebien (1910), and Gebien (1937) synonymized pictus and desertorum with dejeanii.

mucidus [Epitragus] Berg 1883a: 73-74. Tucumán, 4 spec. in coll. Günther and CB.

1 synt., pinned, “Tucumán” printed on green paper glued to a card, abdomen and right elytron missing, "Typus" printed with red ink on white paper. One of us (AOB) added "Epitragus / mucidus / Berg 1883 / Syntypus" handwr. on red cardboard.

Note: There is another spec. labelled "Córdoba" on green paper, which is perhaps not a syntype, as Córdoba was not mentioned by Berg; one of us (AOB) added "Epitragus / mucidus / Berg 1883 / Syntypus?" handwr. on red cardboard. In MLP there are 2 specimens labelled "Typus" and “Tucumán”, probably ex CB.

multigranulosus [Gyriosomus] Pizarro-Araya \& G. Flores 2004: 124-125, Figs. 2, 4, 6. Chile: IV Region, Socos, $200 \mathrm{~m} 30^{\circ} 44^{\prime} \mathrm{S}, 71^{\circ} 31^{\prime} \mathrm{W}$, 25.xi.1987, leg. J.E. Barriga. Holot., allot. in MNS. 121 parat. in MNS, IAD, FMNH, NHMB, UC, 10 in MACN and in other institutions.
10 parat. "Socos, Limarí / IV Region, Chile / 25.xi.1987, J.E. Barriga coll." and " $30^{\circ} 44^{\prime} \mathrm{S} /$ $71^{\circ} 31^{\prime} \mathrm{W} / 200 \mathrm{~m}$ " printed on white paper; "Paratypus" printed on red card; "Gyriosomus / multigranulosus n.sp. / Det. J. Pizarro-Araya/\& G. Flores 2003" printed on white paper.

murinus [Platyolmus, sic, pro Platyholmus] Burmeister 1875: 493-494. Córdoba, two spec., one somewhat smaller, perhaps the female.

2 synt., one of them "Cordova" printed on green paper, the other without labels, and with some parts of it glued to a card on another pin. One of us (AOB) added to both "Syntypus" and "Platyolmus / murinus / Burmeister 1875 / Syntypus" handwr. on red cardboard. Ex HB.

neuquensis [Platesthes] Flores 2004: 603, f. 31, 39, 40. Neuquén: Collon Cura, 29.XII.1958, leg. Gentili, Zapala, 1948, leg. Hayward \& Willink, Marucho, 8.XII.1966, leg. Gentili; holot., allot., 1 paratype in IAD, 2 paratypes in FIML, 1 paratype in MACN.

1 parat. female: "Leg. M. Gentili" handwr. on white paper; "Marucho, Nq., Arg. / 8-XII-1966 / Col. H.J. Molinari" handwr. on white paper; "Paratypus female / Platesthes / neuquensis n. sp. / Det. G. Flores 2003" printed on red card.

neuquensis [Psectrascelis] Peña 1994: 156-157, f. 11, 22. Neuquén: $8 \mathrm{Km}$ N Zapala 30.X.1987 leg. Peña, holot. in MACN, parat. in LP; Neuquén: Laguna Blanca 12.XII.1973 leg. Gentili, allot. in FMNH.

Holot. "8 Km N. Zapala / Neuquén. Arg. / 30X-1987 L.E. Peña" handwr. on white paper; "Psectrascelis / neuquensis o" / n. sp. / Holotypus / det. L.E. Peña 94" handwr. on white paper with a red frame.

nevadoensis [Nyctelia] Flores \& Carrara 2006: 488-489, f. 1, 3-4, 7-8. Mendoza, Malargüe, El Nevado $2908 \mathrm{~m}$ leg. G. Flores-G. Debandi, pitfall 6-16-XII-2004; Mendoza, Malargüe, Río Grande 1950 m, 19-III-1997 leg R. González; Mendoza, San Carlos Reserva Laguna del Diamante 2324 m, leg. G. Flores-G. Debandi, pitfall 8-18-II-2005. Holot., allot. in IAD, 80 paratypes in IAD, FMNH, HNHM, MNHN, MNS, NHMB, BM, MLP, 2 in MACN and in other institutions.

2 parat.: "Argentina. Mendoza/ Dto. Malargüe/ El Nevado 3036 m/ G. Flores-G. Debandi/ pitfall 
6-16-XII-2004" printed on white paper; " $35^{\circ} 35^{\prime}$ $53.0^{\prime \prime} \mathrm{S} / 68^{\circ} 30^{\prime} 34.4^{\prime \prime} \mathrm{W}$ " printed on white paper; "Paratypus" printed on red card; "Nycte-lia/ nevadoensis n. sp. / Det. G. Flores and / R. Carrara 2006" printed on white paper.

nuda [Pilobalia] Peña 1973: 175-176, f. 5, 9, 13, 18, pl. 1: K. Salta: Cachipampa 3200 m, 5.II.1970, holot., allot., 83 parat. in LP, 2 parat. in MACN, other parat. in several institutions.

2 parat. "Cachipampa 3200 m / Salta Argentina / 5-Febr.-1970 / Coll.: L.E. Peña” printed on white paper; "Paratypus" printed on orange-red paper; "Pilobalia / nuda nov. sp. / det.: L.E. Peña 1971" printed on white paper.

nudus [Mitragenius] Berg 1889: 129-130. B. Aires: Tandil, perhaps also more to the South.

1 (sole?) synt. "Typus" printed with red ink on white paper with a red frame; "Tandil" handwr. on green paper; "Mitragenius / nudus / Berg 1889" handwr. by Berg on white paper with a red frame; "Mitragenius / nudus / Berg 1889 [handwr.] / det. H.J. Molinari 1971 [printed]" on white paper; "Mitragenius / nudus / Berg Typus [handwr.] / det. L.E. Peña G. 1986 [printed]”. One of us (AOB) added "Mitragenius / nudus / Berg Typus" handwr. on red cardboard. Ex HB.

nycteloides [Psectrascelis] Peña 1986b: 58-59, f. 2. Salta: Cachipampa 3100-3200 m, 8.X.1968 leg. Peña, in MACN; Salta: Poma 3100 m, 5.IV.1923 leg. Weiser 1 parat. in LP.

Holot. "Argentina / Cachipamapa / 3100-3200 m. Salta / 8.Oct.1968 / Coll.: L.E. Peña" printed on white paper; "Psectrascelis / nycteloides $\mathrm{n}$. sp. (Holotypus) / det. Luis E. Peña G. 1986" handwr. on white paper with a red frame.

Note: Synonymized with Epipedonota sublineata Berg 1901 by Flores \& Vidal (2001: 17-19).

obscuratus [Mitragenius] Peña 1986a: 48-49, f. 11. Salta: Cachipampa 3200 m, holot., male, 16 parat. in MACN; allot., fem., 255 parat. in LP, other parat. in several institutions.

Holot. with genitalia glued to a pointed card; 11 parat., 1 male and $1 \mathrm{fem}$. with plastic microvials containing parts dissected by G. Flores, "Cachipampa $3200 \mathrm{~m} /$ Salta Argentina 5-Febr.1970 / Coll.: L.E. Peña” printed on white paper; the holot. "Mitragenius / obscuratus n.sp. /
Holotypus O / det. L.E. Peña G. 1985" handwr. on white paper with a red frame; the parat. "Paratypus" printed on bright red paper; "Mitragenius / obscuratus n.sp. [handwr.] / det. L.E. Peña G. 1986 [printed]” on white paper. 1 parat. "Salta" handwr. on green paper; 1 parat. "Bs. Aires" printed on green paper; 1 parat. "Escoipe 3500 m / Piedra del Molino / Salta Arg. II.83" handwr. on white paper; 1 parat. without locality label; the last 4 parat. "Mitragenius / dejeani Sol., 1836 / det. H.J. Molinari 1971" handwr. on white paper; "Paratypus" printed on bright red paper; "Mitragenius / obscuratus [handwr.] / det. L.E. Peña G. 1986 [printed]" on white paper.

obtusa [Camaria] Fairmaire 1905: 300-301. Chaco.

1 (sole?) synt. "Rep. Argentina / Gob. Chaco / XI.1897 / C. Bruch" printed on white cardboard, date handwr.; "Typus" printed on pale green paper; "Camaria / obtusa / Fairm. / n. sp." handwr. by Bruch with a red frame; "Camaria obtusa Fm. n.sp." handwr. by Fairmaire, cut and folded. Ex BR.

Note: Peña (letter of 29.VIII.1991) says the type should be in MNHN.

occidentale [Opatrum] Berg 1883b: 396. [La Pampa Prov.?:] Colorado River; name of Lacordaire in coll. Oberthür.

2 synt. "Rio Colorado / A. Doering" handwr. by Berg on white paper; one of them "Typus" printed with red ink on white paper with a red frame. One of us (AOB) added "Opatrum / occidentale / Berg 1883 / Syntypus" handwr. on red cardboard. Ex CB.

Notes: Transferred to Gonocephalum by Gebien (1910: 324), and to Trichoton by Gebien (1939: 464). In MLP there are 3 specimens labelled "Mendoza" and "Typus". The province is uncertain, as the Colorado River makes the boundary between La Pampa and Río Negro Prov.

paraguanum [Bothynocara] Gebien 1928: 173. Paraguay, 1 spec. in coll. Gebien; Corrientes, 1 spec. in BR.

1 synt. "Rep. Argentina / Prov. Corrientes / 190 / C. Bruch" printed on white cardboard; "Cotypus" printed on pale green paper; "Bothynocara / paraguaya [sic] / Geb." handwr. by Bruch on white paper with a red frame; 
"Bothynoca- / paraguaya [sic] Coty- [handwr.] / H. Gebien det. [printed]”, cut. Ex BR.

patagonicus [Calymmophorus] Bruch 1916: 292293, 1 f. Chubut: Puerto Madryn leg. Birabén; Colonia 16 de Octubre leg. Bruch.

1 synt. glued to a card, "Madryn" handwr. by Bruch; "Typus" printed on pale green paper; "Calymmophorus / patagonicus / Bruch" handwr. by Bruch, with a red frame. One of us (GEF) added a label: "Syntypus / Calymmophorus / patagonicus / Bruch 1916 / Det. G. Flores 2006" handwr. on red cardboard. Ex BR.

Notes: In MLP there is another synt., glued to a card, with the same data, but the identification label by Bruch bears a green frame; this is the spec. of the photograph taken and published by Bruch. We were unable to find spec. from Colonia 16 de Octubre.

penai [Gyriosomus] Kulzer 1959: 534-535, pl. 11: 4. Chile: Atacama: El Dieciocho: Totoral 25.X.1957, many spec.; Pampa to the $\mathrm{W}$ of Dieciocho, many spec.; Pta. Varillas Sarco 25.X.1958, many spec.; Coquimbo: Choros Bajos 26.X.1957, many spec., all leg. Peña; holot., allot., parat. in $\mathbf{L P}$, parat. in $\mathbf{M F}$.

1 parat. "Carrizalillo $10 \mathrm{Km}$ SE Atacama 25Oct.-1957 / Coll.: L.E. Peña” printed on white paper; "Paratypus" printed on red paper; "Gyriosomus / penai Klz." handwr. on white paper.

penai [sub peñai] [Praocis] Kulzer 1958a: 79-80, 88, f. 12. [Chile:] Antofagasta: Pocos $2500 \mathrm{~m}$, cordillera Toconao, 25.III.1953. Holot., allot. in LP, parat. in MF; Antofagasta: San Pedro Atacama; El Coigual; Aguas Blancas; Tumbre; cerro Aguas Dulces Quimal, all are parat.

1 parat. "Pocos / Antofagasta / Chile IV.1954 / Coll. L.E. Peña" printed on white paper; "Paratypus" printed on bright orange-red paper; "Praocis / penai / nov. sp. / det. H. Kulzer 1957" printed on white paper.

Note: Currently in Praocis (Orthogonoderes).

peninsularis [Psectrascelis pilipes subsp.] Peña 1974: 117, f. 17, 18. Chile: Coquimbo: Punta de Lengua de Vaca 25.VI.1955, holot., allot., 19 parat.; 223 parat., same but other dates; Coquimbo: Tongoy 8.II.1969. Holot., allot., 205 parat. in LP, other parat. in several institutions.
2 parat. "Lengua de Vaca / Coqbo. Chile / 29.X.1965 / Coll. L.E. Peña” printed on white paper; 1 parat. "Pta. Lengua / de Vaca / Prov. Coquimbo / 31 Julio 1971 / Coll. L.E. Peña". 1 parat. "Prov. Coquimbo / Tongoy / 8.Febr.1969 / Coll. L.E. Peña" printed on white paper. All: "Paratypus" printed on orange-red paper; "Psectrascelis / pilipes / peninsularis / Peña / det. L.E. Peña" printed on white paper.

pentachorda [Praocis] Burmeister 1875: 496. Córdoba.

Lectot. "Cordova" printed on green paper; "Lectotypus / Praocis pentachorda / Burmeister, 1875/ Des. G. Flores 2006" printed on red paper. One of us (AOB) had previously added "Praocis / pentachorda / Burmeister 1875 / Typus" handwr. on red cardboard. Ex HB.

Notes: Currently in Praocis (Postpraocis). Flores (2007a: 418) designated lectot.

perlatus [Scotobius] Burmeister 1875: 464-465. Patagonia: Río Negro: surroundings of Carmen de Patagones; frequent.

1 (sole?) synt. "78", "Carm. / Patag." printed on green paper; one of us (AOB) added "Scotobius / perlatus / Burmeister 1875 / Syntypus" handwr. on red cardboard. Ex HB.

Note: Synonymized with S. casicus [sic] Lacordaire 1830 by Kulzer (1955: 421-422, 459), who also states that the type should be in Halle, but he was unable to found it there. [Burmeister was professor in Halle only until 1860].

perlifera [Emmallodera] Burmeister 1875: 467. Mendoza and Catamarca; perhaps the same as Scotobius cacicus Lacordaire.

1 synt. [Catamarca:] "Copacavana”, printed on green paper. One of us (AOB) added: "Syntypus / Emmallodera / perlifera / Burmeister 1875" handwr. on red cardboard. Ex HB.

Note: Emmallodera perlifera and Scotobius cacicus can be easily identified (G.E. Flores).

peruvianus [Strongylacanthus] Brèthes 1925: 13-14. Perú: Pangoa, leg. C. Rospigliosi Vigil.

1 (sole?) synt. glued to a card (previously pinned, as it has a pin-hole in the right elytron), "Pangoa . Tambo / C. Rospigliosi" handwr. on grayish white paper; "Repreparo / M. Viana / XII-1959" handwr. by Viana; "type!" handwr. by Brèthes; 
"Strongylacanthus / peruvianus Br." handwr. by Brèthes. One of us (AOB) added "Typus" printed on pink cardboard. Ex JB.

pinguis $[$ Nyctelia] Fairmaire 1905: 293. Río Negro.

Lectot. "Rep. Argentina / Gob. Río Negro / XII.1902 / C. Bruch" printed on white cardboard, date handwr.; "Typus" and "Foto" printed on pale green paper; "Nyctelia / pinguis / Fair. tip." handwr. by Bruch, with a red frame; "Nyctelia [cut, with remainings] / pinguis Fm n. sp." handwr. by Fairmaire; "Lectotypus / Nyctelia pinguis / Fairmaire, 1905 / Des. G. Flores 2006” printed on red paper. Ex BR.

Notes: Synonymized with $N$. suturacava Fairmaire 1905 by Kulzer (1963: 26-27, pl. i: 9), who stated that the type was unknown to him, and that there is a parat. in MF, ex coll. Wittmer. Flores (2007a: 422) designated lectot.

planicauda [Nyctelia] Fairmaire 1905: 294-295. Santa Cruz male, female.

Lectot. "Rep. Argentina / Gob. Santa Cruz / IV.1902 / C. Bruch" printed on white cardboard, date handwr.; "Typus" and "Foto" printed on pale green paper; "Nyctelia / planicauda / Fair. tipo" handwr. by Bruch, with a red frame; "planicauda Fm. n.sp." handwr. by Fairmaire, cut, with remainings of "Nyctelia"; "Nyctelia / planicauda (sic, pro laticauda) / Burm. / con tipo comp." handwr. by Bruch, with a green frame; "Lectotypus / Nyctelia planicauda / Fairmaire, 1905 / Des. G. Flores 2006” handwr. on red paper; "=Nyctelia / laticauda / Burmeister, 1877 / Det. G. Flores 2006" handwr. on white paper. Ex BR.

Notes: Flores (2007a: 414-415, f. 2) designated lectot. and synonymized N. planicauda with $N$. laticauda Burmeister (1877: 70).

planiuscula [Epipedonota] Fairmaire 1905: 297. Neuquén.

Lectot. "Rep. Argentina / Gob. Neuquen / 190 / C. Bruch" printed on white cardboard; "Typus" and "Foto" printed on pale green paper; "Epipedonota / planiuscula / Fair. tipo" handwr. by Bruch, with a red frame; "planiuscula Fm. n.sp." handwr. by Fairmaire, cut; " $\mathrm{H}^{4}$ " handwr. on pink paper; "Ep. subplana Geb." handwr. by Bruch, with a green frame; "Epipedonota / subplana Geb.
/ Det. G. Flores - / P. Vidal, 1999" printed on white paper; "Epipedonota planiuscula / Fairmaire, 1905 male / Lectotypus / G. Flores \& P. Vidal Des. 1999" printed on white paper. Ex BR.

Notes: Lectot. designated by Flores \& Vidal (2001: 16-17); E. planiuscula Fairmaire 1905, non Fairmaire 1876 was replaced for E. subplana by Gebien (1910: 145).

porcata $[$ Nyctelia] Burmeister 1877: 70. Río Negro: Nahuel Huapi.

Lectot. and 2 paralectot. Lectot. and 1 paralectot. without labels, the other "Nuah. / Hapi [sic]" handwr. by Burmeister; "Lectotypus [on one] Paralectotypus [on two]/ Nyctelia porcata / Burmeister, 1877/ Des. G. Flores 2006" printed on red paper. One of us (AOB) had previously added to all three "Nyctelia / porcata / Burmeister 1877 / Syntypus" handwr. on red cardboard. Ex HB.

Note: Flores (2007a: 421) designated lectot.

porteri [Omopheres] Brèthes 1919: 170-171. Chile: Blanco River, affluent of Aconcagua River, leg. Porter \& Barros.

1 (sole?) synt. glued to a card (previously pinned, it has a pin-hole in the right elytron), an additional card with mouth appendices glued to it; "Río Blanco / Porter - Barros II. 1918" handwr. on white paper; "Repreparo / M. Viana / I-1960" handwr. by Viana; "Typus" printed on red paper; "Omopheres Porteri Brèthes" handwr. by Brèthes. Ex JB.

producta [Nyctelia] Fairmaire 1905: 295. Patagonia.

Lectot. "Rep. Argentina / Gob. Chubut / III.1900 [?] / C. Bruch" printed on white cardboard, date handwr.; "Typus" printed on pale green paper; "Nyctelia / producta / Fair. tipo" handwr. by Bruch, with a red frame; "Nyctelia [cut, with remainings]/ producta Fm n. sp." handwr. by Fairmaire; "Lectotypus / Nyctelia producta / Fairmaire, 1905 / Des. G. Flores 2006" printed on red paper. Ex BR.

Note: Flores (2007a: 421) designated lectot.

pubescens [Pectinepitragus] Pic 1927: 44. La Rioja: Patquía, ex BR.

Holot. glued to a card, "Rep. Argentina / Prov. La Rioja / 190_/ C. Bruch" printed on white cardboard; "Typus" printed on pale green paper; 
"Pectinepitragus / pubescens / Pic" handwr. by Bruch, with a green frame; "Pectinepitragus $n$. gen. / pubescens mihi” handwr. by Pic. Ex BR.

punctatissima [Psectrascelis] Peña 1985a: 40-41, f. 4c, 18. Catamarca: León Muerto, leg. Weiser 5.III.1923, holot., male, allot., fem., 1 parat. in MACN; 2 parat. in LP.

Holot., male (with genitalia and antennae glued to a card) and allot., fem. "Rep. Argentina / Gob. Los Andes / 5.III.1923 / C. Bruch" printed on white cardboard, date handwr.; "Leon muerto / 5000 m. Weiser" handwr. by Bruch; the holot.: "Psectrascelis / coriaria / Fairm." handwr. by Bruch, with a green frame; "Foto" printed on pale green paper; "R4" handwr.; "Psectrascelis / punctatissima n. sp. / Holotypus [handwr.] / det.: L.E. Peña G. 1983 [printed]" on white paper with a red frame; the allot.: "Psectrascelis sp. 76a" handwr. by Bruch, with a green frame; "Psectrascelis / punctatissima / n. sp. Allotypus [handwr.] / det.: L.E. Peña G. 1983 [printed]" on white paper with a red frame. 1 parat. "Rep. Argentina / Gob. Los Andes / 190_/C. Bruch" printed on white cardboard; "Antofagasta / $3600 \mathrm{~m}$. Weiser" handwr. by Bruch; "Psectrascelis / coriaria / Fairm. 76" handwr. by Bruch; "Paratypus" printed on orange-red paper; "Psectrascelis / punctatissima n. sp. [handwr.] / det.: L.E. Peña G. 1983 [printed]" on white paper with a red frame. Ex BR.

puncticollis [Patagonopraocis] Flores \& Chani Posse 2005: 577-578, f. 1, 6-7, 13, 16. Holot. male in IAD: Neuquén: Chapelco, 1.750 m, 6.II.1972 Leg. M. Gentili, 1 parat. male in MACN, 2 parat. males in IAD same locality of holotype; 2 parat. males in FMNH: Chubut: Esquel, La Hoya, 8001350 m, 24.II.1979, Misión Científica Danesa.

1 parat. male "Neuquén / Chapelco / 7.III.1964" handwrite on white paper; "Paratypus" printed on red card; "Patagonopraocis / puncticollis n. sp. / Det. G. Flores \&/ M. ChaniPosse 2005" printed on white paper.

pustulosus [Entomoderes] Fairmaire 1905: 298. Catamarca.

Lectot. "Rep. Argentina / Prov. Catamarca / II.1893 / C. Bruch" printed on white cardboard, date handwr.; "Typus" printed on pale green paper; "Entomoderes / pustulosus / Fairm." handwr. by Bruch, with a red frame; "Entomoderes / pustulosus Fm. n.sp." handwr. by Fairmaire, cut; "Lectotypus / Entomoderes pustulosus / Fairmaire, 1905 / Des. G. Flores 2006" printed on red paper. One of us (AOB) had previously added “Syntypus". Ex BR.

Note: Flores (2007a: 424) designated lectot.

quadricarinata [Nyctelia] Fairmaire 1905: 293294. Río Negro.

Lectot. and 1 paralectot. "Rep. Argentina / Gob. Río Negro / 3.IV.1898 [on lectot., the other without date] / C. Bruch" printed on white cardboard, date handwr.; "Typus" printed on pale green paper [only on lectot.]; "Nyctelia / 4-carinata / Fair. tip." handwr. by Bruch, with a red frame; "Nyctelia [cut, with remainings] / quadricarinata n. sp." [on lectot.], "4-carinata Fm. n.sp." [on paralectot.] handwr. by Fairmaire; "Lectotypus [on one] Paralectotypus [on the other] / Nyctelia quadricarinata / Fairmaire, 1905 / Des. G. Flores 2006" printed on red paper. Ex BR.

Notes: There is another spec., same locality but "5.III.1898"; "Foto" printed on pale green paper, not labelled as type. Flores (2007a: 423) designated lectot. and 1 paralectot.

quadricollis [Derosimus] Fairmaire 1904: 62. Buenos Aires, sent by Bruch.

4 synt. glued to cards, on one pin "Rep. Argentina / Prov. Buenos Aires / 9.VII.1903 / C. Bruch" printed on white cardboard, date handwr.; "Typus" printed on pale green paper; "Derosimus / quadricollis / Fairm. tipo" handwr. by Bruch, with a red frame; "Derosimus quadricollis" handwr. by Fairmaire, cut. Ex BR

Note: Derosimus was synonymized with Rhypasma by Gebien (1937: 691).

quadricollis [Diastolinus] Fairmaire 1905: 299. Salta.

1 synt.? "Rep. Argentina / Prov. Santa Fé / 190 / C. Bruch" printed on white cardboard; "Rosario" handwr. by Bruch; "Typus" printed on pale green paper; "Diastolinus / quadricollis / Fairm." handwr. by Bruch, with a red frame; "Diastolinus / quadricollis Fm. n.sp." handwr. by Fairmaire, cut. Ex BR.

Notes: The type condition is dubious: The localities differ, but "Salta" may be a mistake for "Santa Fe"; in addition there are localities named 
Rosario in both provinces. Peña (letter of 29.VIII.1991) stated that the type should be in MNHN. Transferred to Opatrinus by Gebien (1938: 416).

quadricollis $[$ Nyctelia] Fairmaire 1905: 296. San Luis.

Lectot. "Rep. Argentina / Prov. San Luis / XII.1900 / C. Bruch" printed on white cardboard, date handwr.; "Typus" and "Foto" printed on pale green paper; "Nyctelia / quadraticollis [sic] / Fair. n.sp." handwr. by Bruch, with a red frame; "quadraticollis [sic] Fm. n.sp." handwr. by Fairmaire, cut, with remainings of "Nyctelia"; "Lectotypus / Nyctelia quadricollis / Fairmaire, 1905 / Des. G. Flores 2006” printed on red paper. Ex BR.

Notes: Nyctelia quadricollis was synonymized with $N$. angustata Waterhouse 1841 by Gebien (1937: 747); later, Kulzer (1963: 60) synonymized $N$. angustata with $N$. brunnipes Latreille 1825. N. quadricollis and $N$. angustata are synonyms with each other on the grounds of the alleged "validsynonym" of $N$. brunnipes, so $N$. quadricollis is synonymous with $N$. brunnipes (Kulzer 1963: 60). Flores (1997) stated that $N$. brunnipes is a posterior synonym of $N$. nodosa (Germar 1824). Flores (2007a: 423) designated lectot.

quadricostatus [Scotobius] Fairmaire 1905: 289290. Catamarca.

Lectot. "Rep. Argentina / Prov. Catamarca XI.1897 / C. Bruch" printed on white cardboard, date handwr.; "Typus" printed on pale green paper; "Scotobius / 4-costatus / Fairm. tipo" handwr. by Bruch, with a red frame; "Scotobius / 4costatus Fm. n.sp." handwr. by Fairmaire, cut; "Lectotypus / Scotobius / quadricostatus / Fairmaire, 1905 / Des. G. Flores 2005” handwr. on red paper. Ex BR.

Notes: Kulzer (1955: 453) in his monography of the Scotobiini did not examine the type specimen(s) of this species, which he said is unknown to him. Flores (2007a: 425) designated lectot.

roigi [Scelidopsecta] Peña 1985b: 88, f. 2. San Juan: Chuto, holot., 3 parat. in MACN, lobata det. Molinari; Mendoza 2 parat.

Holot., 1 parat. "7625” handwr.; "S. Juan Chuto" handwr. on green paper, reverse white; "Scelidopsecta / lobata Burm. 1875 [handwr.] / det.
H.J. Molinari 1971 [printed]" on white paper; on the holot.: "Scelidopsecta / roigi n.sp. / Holotypus [handwr.] / det.: L.E. Peña G. 1984 [printed]" on white paper, with a red frame; on the parat.: "Paratypus" printed on orange-red paper; "Scelidopsecta / roigi n.sp. [handwr.] / det.: L.E. Peña G. 1984 [printed]" on white paper. 1 parat. "S. Juan - Chuto 12.XI.06" handwr.; "Foto" printed on pale green paper; "Scelidopsecta / lobata Burm. 1875 [handwr.] / det. H.J. Molinari [printed]" on white paper. 1 parat. "2632" handwr.; "Mendoza" handwr. on green paper, reverse white; the last two: "Paratypus" printed on orange-red cardboard, and "Scelidopsecta / roigi n.sp. [handwr.] / det.: L.E. Peña G. 1984 [printed]” on white paper.

rotundatus [Psectrascelis] Peña 1994: 154-155, f. 9, 20. Jujuy: Corral Quemado 4000 m, holot., male in MACN, allot., fem., 2 parat. in FMNH, 1 parat. in MNS; 5 parat. in LP; 2 parat. in $\mathbf{P M}$; "Gob. Los Andes", Bruch, 2 parat. one of them identified as intricaticollis.

Holot., male, 1 parat. "Crl. Quemado / 4000 m, Jujuy / Arg. 19-11-92 / leg. L.E. Peña G.” printed on white paper; the holot.: "Psectrascelis / rotundatus / n. sp. / Holotypus o" [handwr.] / det.: L.E. Peña G. 1993 [printed]" on white paper with a red frame; the parat.: "Paratypus" printed on red paper, reverse white; "Psectrascelis / rotundatus / nov. sp. / Det. L.E. Peña - 93" printed on white paper.

rotundipennis [Nyctelia] Fairmaire 1904: 63. Río Negro.

Lectot. "Rep. Argentina / Gob. Río Negro / 17.III.1901 / C. Bruch" printed on white cardboard, date handwr.; "Typus" printed on pale green paper; "Nyctelia / rotundipennis / Fairm. tipo" handwr. by Bruch, with a red frame; "Nyctelia / rotundipennis / Fm. n.sp." handwr. by Fairmaire, cut; "Nyctelia / laticauda / Burm. [handwr. by Bruch] / C. Bruch determ. [printed]" on white paper; "Lectotypus/ Nyctelia/ rotundipennis/ Fairmaire, 1904/ Des. G. Flores 2006" printed on red paper. Ex BR.

Notes: Synonymized with N. laticauda Burmeister 1877 by Gebien (1937: 746); revalidated by Kulzer (1963: 22-23, pl. i: 5). Flores (2007a: 421) designated lectot.

rubrithorax [Strongylium] Brèthes 1920: 38. Perú: Chanchamayo. 
1 (sole?) synt. "Chanchamayo / 1918. C.R. Vigil" handwr. on white paper; "Repreparo / M. Viana / I-1960" handwr. by Viana; "type" and "Strongylium / rubrithorax Brèthes" handwr. by Brèthes. One of us (AOB) added "Typus" printed on red cardboard. Ex JB.

rufofemoralis [Lystronychus (Xystronia)] Borchmann 1930a: 115-116. Paraguay: Altos I.1914, 1 female; Catamarca XII.1896, leg. Bruch, 1 male in coll. Borchmann.

1 synt. glued to a card, "Paraguay / Altos / I.1914" printed, date handwr.; "Typus" printed on pale green paper; "Lystronychus / rufofemoralis / Borchm." handwr. by Bruch, with a red frame; "Lystronychus / rufofemoralis n.sp." handwr. by Borchmann?, cut. Ex BR.

sanjuanina [Epipedonota] Flores \& Vidal 2001: 8, 29-31, f. 36. S. Juan: sierra Pie de Palo: mogote Corralitos, holot., male, allot., fem., 1 parat. in MACN; 2 parat. in IAD.

Holot., male, allot., fem., 1 parat. "San Juan / Sierra Pie de Palo / Mogote Corralitos / XI.1980. M. Cei leg." handwr. on white paper; "Epipedonota / sanjuanina sp. n. / Holotypus male [on the allot.: "Allotypus female"] / G. Flores - P. Vidal 2000" printed on red paper; on the parat.: "Paratypus" printed on red paper; "Epipedonota / sanjuanina sp. n. / G. Flores - P. Vidal 2000” printed on white paper.

semigranosus [Phobelius] Fairmaire 1905: 300. Tucumán.

1 synt. glued on a card "Rep. Argentina / Prov. Tucumán / 9.II.1904 / C. Bruch" printed on white cardboard, date handwr.; "Typus" printed on pale green paper; "Phobelius / semigranosus / Fairm." handwr. by Bruch, with a red frame; "Phobelius / semigranosus Fm. Tucum." handwr. by Fairmaire?, cut. Ex BR.

seminulum [Platyolmus (sic, pro Platyholmus)] Burmeister 1875: 493. Mendoza and Catamarca, found dead; perhaps the variety minor of Solier, called gravidus by Lacordaire.

Lectot., paralectot. "Mendoza”, “46”, and "Catamarca" respectively, printed on green paper. "Platyholmus seminulum / Burmeister, 1875 / Lectotypus [Paralectotypus on the other] / G. Flores Des. 2000" printed on red paper. One of us
(AOB) had added "Syntypus" and "Platyolmus / seminulum / Burmeister 1875 / Syntypus" handwr. on red cardboard. Ex HB.

Notes: Transferred to Thylacoderes by Gebien (1938: 80). Lectot. and paralectot. designated by Flores (2000b: 84-85, f. 2, 8, 23). The 'var.' minor (= gravidus) occurs in Chile, where Platyholmus does not occur; it probably refers to Entomochilus Gay \& Solier.

sericeipes [Allecula] Borchmann 1930b: 88, pl. iii: 3. Córdoba: Alta Gracia, at electric light, several males and females.

4 synt., 3 of them pinned, 1 glued to a card, one of them "Alta Gracia / Córd. III.921" handwr. by Bruch, the other 3 "Alta Gracia. La Granja / Sierras de Córdoba / I.922 [on one, the other II.922, 26.I.927] / C. Bruch" printed on white paper, dates handwr. On three of them "Typus" printed on pale green paper; "Fototipo" printed on pale green paper; "Allecula / sericeipes / Borchm." handwr. by Bruch, with a red frame [without a frame in the last one]; "Allecula / sericeipes" [on one], "Allecula / sericeipes n.sp." [on two] handwr. by Borchmann?, cut. BR.

setipennis [Nyctelia] Flores \& Carrara 2006: 489491, f. 2, 5-6, 7-9. Mendoza, Las Heras, 2824 m, 7 $\mathrm{km}$ E of Paramillos, leg G. Flores-S. Claver, pitfall 6-16-XII-2004; Mendoza, Las Heras, 2958 m, Paramillos Uspallata, leg S. Roig, 10-II-2005; Mendoza, Las Heras, $5 \mathrm{~km}$ E of Villavicencio, 1450 m, 14-I-1999, leg. G. Flores. Holot., allot. in IAD, 27 paratypes in IAD, FMNH, HNHM, MNHN, MNS, NHMB, BM, 2 in MACN.

2 parat.: "Argentina. Mendoza/ Dto. Las Heras $2824 \mathrm{~m} / 7 \mathrm{~km}$ E of Paramillos/ G. Flores-S. Claver/ pitfall 6-16-XII-2004" printed on white paper; " $32^{\text {ㅇ }}$ $30^{\prime} 02.7^{\prime \prime} \mathrm{S} / 69^{\circ} 04^{\prime}$ 03.2' ' W" printed on white paper; "Paratypus" printed on red card; "Nyctelia/ setipennis n. sp./ Det. G. Flores and/ R. Carrara 2006" printed on white paper.

sphaericus [Pimelosomus] Burmeister 1875: 489-490. Near Fort San Carlos, to the South of Mendoza; a single specimen.

Holot. "Pampa / occid." printed on green paper; "744" printed; "1" handwr. One of us (AOB) added "Holotypus" printed and "Pimelosomus / sphaericus / Burmeister 1875" handwr., both on red cardboard. Ex HB. 
Note: "Pampa occidental" is a vague, old reference to the great area including western La Pampa, southern San Luis, and the southern half of Mendoza Provinces.

strigosicollis [Epipedonota] Fairmaire 1904: 6364. Catamarca: Cerro Negro, $4000 \mathrm{~m}$, several spec.

Lectot. and 1 paralectot. "Rep. Argentina / Prov. Catamarca / 7.I.1897 [on lectot.; "II.1897" on paralectot.] / C. Bruch" printed on white cardboard, date handwr.; "Typus" printed on pale green paper; on lectot.: "Cerro Negro / 4000 m" handwr. by Bruch; "Epipedonota / strigosicollis Fm. n. sp." handwr. by Fairmaire, cut; "Lectotypus / Epipedonota / strigosicollis / Fairmaire, 1904 / Des. G. Flores 2005" handwr. on red paper. On paralectot.: "Foto" printed on pale green paper; " $\mathrm{U}^{2}$ " handwr. on pink paper. One of us (AOB) had previously added "Epipedonota / strigosicollis / Fairmaire 1904 / Syntypus" handwr. on red cardboard; "Paralectotypus / Epipedonota / strigosicollis / Fairmaire, 1904 / Des. G. Flores 2005" handwr. on red paper. Ex BR.

Note: Transferred to Psectrascelis by Gebien (1937: 751). Flores (2007a: 423-424) examined the whole series and designated lectot. (MACN) and 3 paralectot (1 MACN, 2 MNHN).

subauratus [Entomoderes] Burmeister 1875: 486. Probably from Córdoba.

2 synt. "Cordova" printed on green paper. One of us (AOB) added "Syn- / typus" printed, and "Entomoderes / subauratus / Burmeister 1875 / Syntypus" handwr. on red cardboard. Ex HB.

Notes: There is a third spec., without labels, which may be a syntype too. The type locality, Córdoba, is probably, as the species occurs in northern La Rioja and southern Catamarca Provinces (Flores \& Roig Juñent 1997).

subcostatus [Cardiogenus] Burmeister 1875: 469. [Uruguay:] Montevideo.

2 synt., one of them "Banda / Orient." [= Uruguay] printed on green paper, the other without labels. One of us (AOB) added "Cardiogenus / subcostatus / Burmeister 1875 / Syntypus" handwr. on red cardboard ["Syntypus?" on the spec. without labels]. Ex HB.

Note: Recorded as C. cicatricosus Solier var. subcostatus by Haag-Rutemberg (1876: 108); status considered dubious by Burmeister (1877: 68); recorded as C. subcostatus by Gebien (1910: 139). sublineata [Epipedonota] Berg 1901: 270-271. Salta: "Cachi Pampa, etc.", three spec. at the Museum [MACN].

Lectot.: "Typus" printed with red ink on white paper; "Salta" handwr. on green paper; "Foto Bruch" handwr.; "sublineata Berg" handwr. by Berg on white paper; "Epipedonota / sublineata / Berg Typus [handwr.] / det. L.E. Peña G. 198 [printed]" on white paper; "Epipedonota / sublineata / Berg / Lectotypus / G. Flores \& P. Vidal Des. 1999" printed on red paper. 2 paralectot.: "4227", "Cachipampa / Pr. Salta" handwr. on green paper; "Epipedonota / sublineata / Berg / Paralectotypus / G. Flores \& P. Vidal Des. 1999" printed on red paper. One of us (AOB) had previously added to all three "Epipedonota / sublineata / Berg 1901 / Syntypus" handwr. on red cardboard. Ex CB.

Note: Lectot. and paralectot. designated by Flores \& Vidal (2001: 17-19), who considered Psectrascelis nycteloides Peña 1986 as a synonym.

subtestacea [Lobopoda] Brèthes 1910: 206-207. Bolivia.

1 (sole?) synt. glued to a card, with a pin-hole in the right elytron (as it was previously pinned) "Bolivia" handwr. on green paper, reverse white; "Repreparo / M. Viana / I.1960" handwr.; "10256" handwr.; "Lobopoda / subtestacea Brèthes" handwr. by Brèthes on white paper. One of us (AOB) added "Typus" printed on red cardboard.

tenuicornis [Lystronychus] Borchmann 1930a: 82, 95-96. Córdoba: Alta Gracia III.1921, II.1922, leg. Bruch, 3 spec.; Paraguay 1 male in coll. Borchmann.

2 synt. glued to cards, on 2 pins, "Alta Gracia. La Granja / Sierras de Córdoba / C. Bruch leg." printed on white paper; "Typus" printed on pale green paper; one of them also "Lystronychus / tenuicornis / Borchmann" handwr. by Bruch, with a red frame; "Lystronychus / tenuicornis n.sp." handwr. by Borchmann?, cut. One of us (AOB) added to the other one "Lystronychus / tenuicornis / Borchmann 1930 / Syntypus?" handwr. on red cardboard.

tenuimembris [Eustenia] Fairmaire 1905: 303. Tucumán.

1 (sole?) synt. glued to a card "Rep. Argentina / Prov. Tucumán / 10.VII.1900 / C. Bruch" printed on white cardboard, date handwr.; "Typus" 
printed on pale green paper; "Eustenia / tenuimembris / Fairm. / n.g. tipo" handwr. by Bruch, with a red frame; "Eustenia / tenuimembris" handwr. by Fairmaire?, cut; "Tucumana / tenuimembris / (Fairm.) Gebien" handwr. by Bruch, with a black frame.

Note: Eustenia Fairmaire 1905 is a homonym of Eustenia Snell 1899. Gebien (1911: 604) proposed Tucumana as a replacement name.

tenuis [Dietopsis] Fairmaire 1905: 302. Tucumán.

1 (sole?) synt. glued to a card, "Rep. Argentina / Prov. Tucumán/XII.1899/C. Bruch" printed on white cardboard, date handwr.; "Typus" printed on pale green paper; "Dietopsis / tenuis / Fairm.", "Allecula / neglecta / Borchm." both handwr. by Bruch, with a red frame. Ex BR.

Note: Dietopsis was downgraded to a subgenus of Allecula by Borchmann (1909: 714); $D$. tenuis Fairmaire 1905 is a homonym of $D$. tenuis Marseul 1876, and of D. tenuis Fairmaire 1894. Borchmann (1909: 714) proposed neglecta as a replacement name.

timarchoides [Nyctelia] Fairmaire 1905: 291. Patagonia, male, female.

Lectot. "Rep. Argentina / Gob. Santa Cruz / II.1901 / C. Bruch" printed on white cardboard, date handwr.; "Typus" printed on pale green paper; "Nyctelia / timarchoides / Fairm. tipo" handwr. by Bruch, with a red frame; "Nyctelia [cut, with remainings] / timarchoides Fm. n.sp." handwr. by Fairmaire; "Lectotypus / Nyctelia timarchoides / Fairmaire, 1905 / Des. G. Flores 2006" printed on red paper. Ex BR.

Notes: Synonymized with $N$. guerini Waterhouse 1841 by Gebien (1937: 748). Flores (2007a: 421-422) designated lectot.

tricostata [Epipedonota] Burmeister 1875: 479480. Patagonia: Weddell-Bluff, also to the SW, in the Pampas (sic); frequent.

Lectot. and 3 paralectot., the first: "Foto Bruch" handwr. on pink paper; " 55 " printed on green paper; "Epipedonota / tricostata / Burmeister / Lectotypus [on this] Paralectotypus [on the other three] / G. Flores \& P. Vidal Des. 1999" the second: " $O$ " " handwr. on green paper; "S. Cruz / Patag." printed on green paper; the third: without labels; the fourth: " $O$ " handwr. on green paper. One of us (AOB) had previously added to all four "Epipedonota / tricostata / Burmeister 1875 / Syntypus" handwr. on red cardboard. Ex HB.

Notes: The third and the fourth spec. are smoother, as mentioned by Burmeister; Berg (1901: 267) redescribed these synt. Lectot. and 3 paralectot. were designated by Flores \& Vidal (2001: 9). The species occurs only in the Provinces Santa Cruz (Argentina) and Magallanes (Chile) (Flores \& Vidal, 2001).

triplehorni [Caenocrypticoides] Flores \& Pizarro-Araya 2004: 722-723, f. 5-11. Argentina, Mendoza, Las Heras Department, Araucarias de Darwin, Sierra de Uspallata, $2730 \mathrm{~m}, 32^{\circ} 28^{\circ} \mathrm{S}$, $69^{\circ} 09^{\prime}$ W, 27.IX.2003, leg. G. Flores; holot., allot. in IAD, 1 parat. in MACN, MNS, HNHM.

1 parat. "Argentina, Mendoza / Dto. Las Heras $2730 \mathrm{~m} /$ Araucarias de Darwin / Sierra de Uspallata / 27.IX.2003 G. Flores" " $32^{\circ} 28^{`} \mathrm{~S}, 69^{\circ}$ 09' W" printed on white paper; "Caenocrypticoides / triplehorni n. sp. / Paratypus / Det. G. Flores \& /J. Pizarro-Araya 2004" printed on red paper.

tristis [Mitragenius] Kulzer 1959: 558-559. Chile: Malleco: Pino Hachado 1800-2000 m, leg. Peña, 2 parat. in MACN; holot., allot., parat. in LP, 13 parat. in AMNH, 2 parat. in MNS, 1 parat. in HNHM, 2 parat. in IAD, MF.

1 male, 1 fem. parat. "Pino Hachado / 18002000 m / Malleco / 6, 10-Enero-59 / Coll. L.E. Peña" printed on white paper; "Paratypus" printed on red paper; "Mitragenius / tristis nov. sp. / Kulzer" printed on white paper.

Note: These parat. were sent by AMNH to one of us (GEF) in order to be deposited in MACN.

tucumana [Epipedonota] Flores \& Vidal 2001: $8,21-23$, f. 34. Tucumán, between Infiernillo and Amaicha, holot., male , 2 parat. in FIML, 1 parat. in IAD; other parat. Amaicha to Tafí; Tafí to Cumbres Calchaquíes; Catamarca: Santa María, and without known locality, in MACN (3), IAD, FIML, MNS, FMNH, MLP, BM.

3 parat., 2 of them: "Col. / A. Breyer" printed on white paper with a black frame; "Paratypus" printed on red paper, one of these "Epipedonota / monilis / Lac., 1830 [handwr.] / det. H.J. Molinari 1971 [printed]" on white paper, the other "Epipedonota / angusta Burm. [handwr.] / Det. Köhler [printed]" on white paper, with remainings 
of a black frame; "Epipedonota / monilis / angustata / Burm. 1875 [handwr.] / det. H.J. Molinari 1971 [printed]" on white paper. The remaining one: "Paratypus" printed on red paper; "Epipedonota / monilis / Lac., 1830 [handwr.] / det. H.J. Molinari 1971 [printed]" on white paper. All three "Epipedonota / tucumana sp. n. / Det. G. Flores - P. Vidal 2000" printed on white paper.

unicostata [Nyctelia] Fairmaire 1905: 294. Santa Cruz.

Lectot. "Rep. Argentina / Gob. Santa Cruz / 15.II.1900 / C. Bruch" printed on white cardboard, date handwr.; "Typus" printed on pale green paper; "Nyctelia / unicostata / Fair. tipo." handwr. by Bruch, with a red frame; "Nyctelia [cut, with remainings] / unicostata Fm. n. sp." handwr. by Fairmaire; "Lectotypus / Nyctelia unicostata / Fairmaire, 1905 / Des. G. Flores 2006” printed on red paper. Ex BR.

Notes: There is another spec., same locality but no date, labelled "Foto", printed on pale green paper. Flores (2007a: 422-423) designated lectot.

ursina [Psectrascelis] Burmeister 1875: 475. Catamarca and Córdoba.

3 synt., one of them "Cordova" printed on green paper, the other two without labels. One of us (AOB) added "Psectrascelis / ursina / Burmeister 1875 / Syntypus" handwr. on red cardboard. Ex HB.

Note: To the left of the first spec. a pin-hole in the bottom of the drawer suggests a further specimen.

validus [Opatrinus] Burmeister 1875: 499. Tucumán.

1 (sole?) synt. "Tucumán” printed on green paper. One of us (AOB) added "Typus" and "Opatrinus / validus / Burmeister 1875 / Typus" handwritten on red cardboard. Ex HB.

Note: Gebien (1938: 416) considered that Diastolinus acuticollis Fairmaire 1905 is a synonym.

vianai [Lepidocnemeplatia] Kaszab 1966: 43-45. La Pampa: Cuchilloco, leg. Copello, ex coll. Brèthes, holot. in MACN.

Specimen missing. 2 cards, "Pampa 1913 / Cuchilloco / Dr. A. Copello" handwr. on white paper; "Holotypus" [printed with red ink] / 1965 / Lepidocnemeplatia / vianai / Kaszab [handwr.]" on white paper with a red frame; "Lepidocnemeplatia / vianai Kaszab [handwr.] / Z. Kaszab det. 1965 [printed]" on white paper.

vidali [Psectrascelis] Peña 1985a: 34-36, f. 15, pl. vi. Bolivia: Potosí; Jujuy, 6 parat. in MACN. Holot., allot., 34 parat. in LP, other parat. in several institutions.

2 parat. "Sta. Catalina / Jujuy 19.I.21" handwr. by Bruch; one of them "Psectrascelis n.sp. / aff. laevigata / Er. 75" handwr. by Bruch; 1 parat. "Rep. Argentina / Prov. Jujuy / 27.III.1909 / C. Bruch" printed on white cardboard, date handwr.; "Pucapampa / Sta. Catalina" handwr. by Bruch; "Foto" printed on pale green paper; "Ps. n.sp. / aff. laevigata Er." handwr. by Bruch, with a green frame; all these ex BR. 6 parat. "Alcalá Potosí / 3800 m. Bolivia 25.II.1976 / Coll. L.E. Peña" printed on white paper. 1 parat. ex coll. A. Martínez, "Alcalá 3800 $\mathrm{m}$ / Potosí / Ventilla / 28.II.76. Bolivia / L.E. Peña G." handwr. on white paper. 1 parat. "Lenas / 4000 m - 28.II.76 / Potosí Bolivia / Coll. L.E. Peña" printed on white paper. All: "Paratypus" printed on orange-red paper, and "Psectrascelis / vidali n.sp. [handwr.] / det.: L.E. Peña G. 1983 [printed]" on white paper.

wagneri [sub Wagneri] [Lystronychus] Pic 1921: 14. Argentina. [More than 1 spec., as the measurements are given as a range].

1 synt. glued to a card "Rep. Argentina / Pr. Santiago d. Estero / 190_/ C. Bruch" printed on white cardboard; "Cotypus" handwr. on pale green paper; "Lystronychus / Wagneri / Pic" handwr. by Bruch, with a green frame; "Lystronychus / Wagneri Pic" handwr. by Pic?, cut. Ex BR.

zupay [Entomoderes] Flores \& Roig Juñent 1997: 143, 146-147, f. 4, 11, 23, 24, 38, 50. Salta: Cachipampa, 1 parat. in MACN. Holot. male, allot. fem., parat. in IAD; other parat. in MLP, FIML. Salta, 1 parat. in FIML.

1 parat. with genitalia in a plastic microvial, “Arg.-Salta / Cachipampa / M. Viana. II.1989" handwr. on white paper; "Paratipo $\sigma^{7}$ " handwr. on red paper; "Entomoderes / zupay / Flores \& Roig" printed on white paper. 


\section{SPECIMENS LABELLED AS TYPES BUT NOT FOUND IN THE BIBLIOGRAPHY AND SEEMINGLY NOT PUBLISHED}

\section{insolita [Camaridia] Fairmaire}

1 spec. "Rep. Argentina / Pr. Santiago d. Estero / 190_ / C. Bruch" printed on white cardboard; "Typus" printed on pale green paper; "Camaridia / insolita / Fairm. tipo" handwr. by Bruch on white paper, with remainings of a black frame; "Camaridia insolita Fm n.g. n.sp." handwr. by Fairmaire?, cut. Ex BR.

Note: Not recorded in Zoological Record, nor in catalogs (Gebien 1910, 1942, Blackwelder 1945). Even the genus seems not to have been published.

\section{jujuyensis [Megalophrys] Bruch}

15 spec. glued to cards, on 5 pins "Rep. Argentina / Prov. Jujuy / 22.V.1920 / C. Bruch" printed on white cardboard, date handwr.; "Typus" (on 2 pins), "Cotypus" (on 3 pins) printed on pale green paper; "Megalophrys / jujuyensis / Bruch" handwr. by Bruch (missing on one pin, to which one of us (AOB) added "Megalophrys / jujuyensis / Bruch" handwr. on red cardboard). Ex BR.

Notes: Not recorded in Zoological Record, nor in catalogs (Gebien 1910, 1937, Blackwelder 1945). The specimens was identified by G.E. Flores in 2006 as Ambigatus sp. (label handwr. on white paper).

\section{laeviusculus [Phobelius] Fairmaire}

1 spec. glued to a card "Rep. Argentina / Gob. Misiones / 4.VIII.1904/C. Bruch" printed on white cardboard, date handwr.; "Typus" printed on pale green paper; "Phobelius / laeviusculus / Fairm" handwr. by Bruch on white paper with a red frame; "Phobelius / laeviusculus" handwr. by Fairmaire?, cut. Ex BR.

Note: Not recorded in Zoological Record, nor in catalogs (Gebien 1910, 1941, Blackwelder 1945).

\section{pubescens [Platesthes] Bruch}

1 spec. "Rep. Argentina / Gob. Río Negro / 190 / C. Bruch" printed on white cardboard; "Typus" printed on pale green paper; "Platesthes pubescens Bruch" handwr. by Bruch, with a red frame. Ex BR.

Notes: Not recorded in Zoological Record, nor in catalogs (Gebien 1910, 1938, Blackwelder
1945). The specimen was identified in 2002 by one of us (GEF) as Platesthes pilosa Kulzer 1956 (label handwr. on white paper).

\section{seriegranatus [Scotobius] Fairmaire}

1 spec. "Cotypus" printed on pale green paper; "Scotobius / seriegranatus / Fairm." handwr. by Bruch, with a red frame; "-cotobius seriegranatu-" handwr. by Fairmaire, cut. Ex BR.

Note: Not recorded in Zoological Record, nor in catalogs (Gebien 1910, 1937, Blackwelder 1945).

\section{simplicicollis [Antimachus] Fairmaire}

1 spec. "Rep. Argentina / Gob. Misiones / 190 / C. Bruch" printed on white cardboard; "Typus" printed on pale green paper; "Antimachus / simplicicollis / Fairm. tipo" handwr. by Bruch, with a red frame. Ex BR.

Note: Not recorded in Zoological Record, nor in catalogs (Gebien 1910, 1940, Blackwelder 1945).

\section{SPECIMENS LABELLED AS TYPES BUT NOT INCLUDED IN THE ORIGINAL SERIES}

argentinus [Lystronychus] Pic 1921: 13-14. Argentina.

1 spec. glued to a card "Alta Gracia. La Granja / Sierras de Córdoba / XII.923 / C. Bruch" printed on white paper, date handwr.; "Sobre Acacia lutea Mill." handwr. by Bruch; "Typus" handwr. by Bruch on pale green paper; "Lystronychus / argentinus / Pic" handwr. by Bruch, with a red frame; "Lystronychus / argentinus / Pic" handwr., seemingly by Borchmann, cut. Ex BR.

Note: The spec. was collected after the publication date.

borchmanni [Camaria] Gebien 1919: 111-112. Brasil: Rio Grande do Sul, 23 spec. in Mus. Berlin and other European coll.

1 spec. "Bompland / Jörgensen" printed; "Cotypus" printed on pale green paper; "Camaria / Borchmanni [handwr.] / H. Gebien det. [printed]" on white paper. Ex BR.

Note: Bompland (Misiones Prov.) was not mentioned in the original description.

bucculata [Dietopsis] Fairmaire 1905: 302. Tucumán; [Uruguay:] Montevideo.

1 spec. "Rep. Argentina / Prov. Córdoba / 25.I.1899 / C. Bruch" printed on white cardboard, 
date handwr.; "Typus" printed on pale green paper; "Allecula / (Dietopsis) bucculata / Fairm." handwr. by Bruch, with a red frame; "Dietopsis / bucculata" handwr. by Fairmaire?, cut. One of us (AOB) added "Dietopsis / bucculata / Fairmaire 1905 / Syntypus?" handwr. on red cardboard. Ex BR.

Notes: Córdoba was not mentioned in the original description. Dietopsis is included in Allecula as a subgenus.

deserti [Argyrophana] Semenow 1890: 224-225. Prov. Transcaspica: Repetek, in the desert, $6 \mathrm{mu}$ tilated spec. leg. Russanow 1888.

1 spec. "cotype" typed on dark red paper, reverse white; "Kara-Kum Wüste / Transkaspien / H. v.Bodemeyer" printed on white paper; " 145 " printed; "153" typed; "Argyrophana / deserti / Semen. 1890 [handwr.] / det. H.J. Molinari 1970 [printed]" on white paper.

Note: The spec. obviously does not belong to the typical series collectad by Russanow.

griseolineatus [Lystronychus (Lystronychus)] Borchmann 1930a: 83, 97-98. Córdoba: S. Vicente, leg. Frenzel, 2 spec.; Santiago del Estero, 1 spec. in Museum Berlin.

1 spec. glued to a card "Alta Gracia. La Granja / Sierras de Córdoba / 14.II.927 C. Bruch leg." printed, date handwr.; "Typus" handwr. by Bruch on pale green paper; "Lystronychus / griseolineatus / Pic" handwr. by Bruch, with a green frame; "Lystronychus griseolineatus n.sp." handwr. Ex BR.

Note: The locality was not mentioned in the original publication; Bruch refers the name to Pic.

humeralis [Lystronychus] Fairmaire 1905: 302303. Tucumán.

2 spec. glued to cards, on 2 pins "Rep. Argentina / Prov. Tucumán / V.1908 / C. Bruch" printed on white cardboard, date handwr.; "Typus" printed on pale green paper. One of them "Lystronychus / humeralis / Fairm. tipo" handwr. by Bruch, with a red frame; "Lystronychus / humeralis" handwr. by Fairmaire, cut. Ex BR.

Note: The spec. were collected after the publication date.

macilenta [Priocamaria] Gebien 1919: 144-145, pl. ii: 22. Mendoza, 1 male in coll. Gebien.
1 spec. "Rep. Argentina / Prov. Catamarca / 190_ / C. Bruch" printed on white cardboard; "Agua Amarilla / Weiser leg." handwr. by Bruch; "Cotypus" printed on pale green paper; "Priocamaria / macilenta / Geb." handwr. by Bruch, with a red frame; "Priocamaria / macilenta [handwritten] / H. Gebien det. [printed]" on white paper, cut. Ex BR.

Note: Gebien mentioned a single specimen from Mendoza; Catamarca was not mentioned by him.

nervosa [Praocis] Fairmaire 1902: 149. "Santiago de Chuco, N Pérou" [probably more than one spec., as the length is given as "10 à 11 mill."]

1 spec. "Pérou" printed on gray paper, with remainings of a black frame; "Praocis / nervosa / cotipo Fairm." handwr. by Bruch, with a red frame. Ex BR.

Notes: This specimen does not have the label data of collecting "Santiago / Pérou" and "Baer" [coll.] nor the handwr. by Fairmaire observed by one of us (GEF) in the syntypes housed at MNHN. Kulzer (1958b: 190-191) and Flores (2001: 174) stated the type is in MNHN. The species was designated the type of Praocidia by Fairmaire (1903: 463). Flores (2007a: 420) designated lectot. and 1 paralect. in MNHN.

opacus [Paroeatus] Gebien 1928: 179-180. [Brasil:] São Paulo, near Ribeirão Preto. Fundão VII-1898 - III-1899; Ytu: Campinas Funil. V.1902.

1 spec. "Misiones / Bompland" printed on white paper; "Cotypus" printed on pale green paper; "Paroeatus / opacus / Geb." handwr. by Bruch, with a red frame; "Paroeatus opacus Geb. [handwr.] / H. Gebien det. [printed]", cut. Ex BR.

Note: Misiones was not mentioned in the original description.

rufocastaneus [Epitragus] Fairmaire 1892: 247248. La Rioja, male, female.

1 spec. "Rep. Argentina / Prov. San Luis / 9.I.1900 / C. Bruch" printed on white cardboard, date handwr.; "Typus" printed on pale green papewr; "Epitragus / rufocastaneus / Fairm. n. sp." handwr. by Bruch, with a red frame; "Epitragus / rufocastaneus" handwr. by Fairmaire?, cut, with remainings of "Fm." Ex BR.

Notes: The spec. was collected after the publication date. Recorded as Omopheres rufocastanea 
by Gebien (1937: 570) and Blackwelder (1945: 511); Freude (1967: 235-236) transferred this species to Eunotiodes Casey, and considered that spissus Kulzer 1958 is a synonym.

simplex [Goniadera] Fairmaire 1889: xxxviiixxxix. Brasil: Minas Gerais. [The measurements are given as a range, suggesting several spec.]

1 synt. "Rep. Argentina / Gob. Misiones / 190 / C. Bruch" printed on white cardboard; "Typus" printed on pale green paper; "Goniadera / simplex / Fairm. tipo" handwr. by Bruch, with remainings of a black frame; "Goniadera simplex" handwr. by Fairmaire, cut., glued on a bigger label "orig. manuscr. / de Fairmaire" (handwr. by Julio Ferrer); "Holotype 우 / Goniadera / simplex / Fairmaire / Det. J. Ferrer" (handwr. by Julio Ferrer). Ex BR.

Note: Argentina and Misiones were not mentioned in the original description and it seems the spec. was collected after the publication date. J. Ferrer (pers. comm.) did not find type specimens of Goniadera simplex in MNHN nor in other museums.

suturacava [Nyctelia] Fairmaire 1905: 291-292. Río Negro, male and female.

2 spec. "Rep. Argentina/ Gob. Río Negro / 190 / C. Bruch" printed on white cardboard; "Cotypus" printed on pale green paper; one of them "Nyctelia / suturacava / Fairm." handwr. by Bruch, with a red frame; the other one "Foto" printed on pale green paper. Ex BR.

Notes: The type condition is dubious, as the spec. lack a label handwritten by Fairmaire. There are 3 further spec. from the same locality, not labelled as types. Kulzer (1963: 26-27, pl. i: 9) stated the type is in MNHN, and considered that $N$. pinguis Fairmaire 1905 is a synonym. One of us (GEF) added a label on one of them (in Spanish): "Not types, does not have handwr. by Fairmaire and $13 \mathrm{~mm}$ length (type in MNHN) Det. G. Flores 2006". On reverse: "The spec. used for the description are 15-16 mm length" handwr. on white paper.

vageimpressa [Nyctelia] Fairmaire 1904: 62-63. Catamarca [the measurements are given as a range, suggesting several spec.]

1 spec. "Rep. Argentina / Gob. Río Negro / 10.II.1901 [?] / C. Bruch" printed on white cardboard, date handwr. and hardly readable; "Typus" printed on pale green paper; "Nyctelia / vageimpressa / Fairm. n.sp." handwr. by Bruch, with a red frame. Ex BR.

Notes: Río Negro was not mentioned in the original description. The specimen was identified in 2006 by one of us (GEF) as Nyctelia rotundipennis Fairmaire, 1904 (label handwr. on white paper). Flores (2007a: 414-415) designated lectot. of $N$. vageimpressa in $\mathbf{M N H N}$ and considered that N. bifoveata Fairmaire 1905 is a synonym.

\section{ACKNOWLEDGEMENTS}

We gratefully acknowledge to the reviewers for suggestions for improving this paper. This study was supported by the Consejo Nacional de Investigaciones Científicas y Técnicas (CONICET) and by a grant of the BBVA Foundation, Spain: "Diseño de una red de reservas para la protección de la biodiversidad en América del Sur Austral utilizando modelos predictivos de distribución con taxones hiperdiversos" (GEF).

\section{BIBLIOGRAPHY}

Aalbu, R.L. 2006. Where are we at: assessing the currents state of Tenebrionidae systematics on a global scale (Coleoptera: Tenebrionidae). Cahiers scientifiques (Muséum d'Histoire naturelle, Lyon) 10: $55-70$.

Berg, C. 1883a. Doce heterómeros nuevos de la fauna argentina. Anls. Soc. cient. argent. 15: 66-78.

- $\quad$ 1883b. Zur Pampa-Fauna. Stettiner entom. Zeitg. 44: 392-396.

- 1889. Quadraginta Coleoptera nova argentina. Anls. Univ. B. Aires 4: 105-157.

- 1901. De nonnullis speciebus argentinis cognitis aut novis generis Epipedonota Sol. Comun. Mus. nac. B. Aires 1 (8): 267-272.

Blackwelder, R.E. 1945. Checklist of the Coleopterous insects of Mexico, Central America, the West Indies, and South America. Part 3. Bull. U. S. nation. Mus. 185 (3): i - iv, 343-550.

Borchmann, F. 1909. Systematische und synonymische Notizen über Lagriides und Alleculiden. Deutsche entom. Zeitschr. 1909: 712-714.

- 1912. Neue Heteromeren aus Argentinien (Col.). Deutsche entom. Zeitschr. 1912: 386-390.

- $\quad$ 1930a. Die Gattung Lystronychus Latr. (Col. Allec.). Deutsche entom. Zeitschr. 1930 (2-3): 81-121.

1930b. Alleculidae y Meloidae descriptas por Fr. Borchmann (Hamburgo). Rev. Soc. Entomol. Argent. 3 (13): 85-100. [Translation by C. Bruch]

Bouchard, P., J.F., Lawrence, A.E. Davis \& A.F. Newton. 2005. Synoptic classification of the world Tenebrionidae (Insecta: Coleoptera) with a review of family-group names. Ann. Zool. 55(4): 499-530.

Brèthes, J. 1910. Coleópteros argentinos y bolivianos. Anls. Soc. cient. argent. 69: 205-227. 
- 1919. Cueillette d'insectes au Rio Blanco. Revta. chilena Hist. nat. 22 (5-6), 1918: 161-171.

- 1920. Insectes du Pérou. Anls. Soc. cient. argent. 89: 27-54.

- 1925. Nouveaux coléoptères sudamericains. Nunquam otiosus, B. Aires 4: 11-16.

Bruch, C. 1916. Descripción de un nuevo Tenebriónido del Chubut ("Calymmophorus patagonicus" Bruch n. sp.). Physis, Buenos Aires 2 (11): 292-293, $1 \mathrm{f}$.

Burmeister, H. 1875. Melanosoma Argentina. Stettiner entom. Zeitg. 36 (10-12): 457-500.

- 1877. Zur Synonymie der Gattung Cardiogenius. Stettiner entom. Zeitg.38: 68 .

Español Coll, F. 1955. Los Crypticini paleárticos (Col. Tenebrionidae). Eos 31 (1-2): 7-38.

Fairmaire, L. 1876. Révision des Coléoptères du Chili. Famille des Tenebrionidae, Tribu des Nyctélites. Annls. Soc. entom. France 5 (6): 143-170, 341-383.

- 1889. Quelques Hétéromères de Minas Geraes (Brésil). Annls. Soc. entom. Belgique 33, Bull. ou Comptes rend. xxxii-1.

- 1892. Descriptions de quelques Coléoptères argentins. Annls. Soc. entom. Belgique 36: 242-253. 1902. Diagnoses de Coléoptères hétéromères recueillis par M. G.-A. Baer au Pérou. Bull. Soc. entom. France (1902): 148-151.

- 1903. Coléoptères hétéromères recueillis par M. Baer dans le Haut-Pérou et le Tucuman. Annls. Soc. entom. France 72: 461-468.

- 1904. Descriptions de Coléoptères de la République Argentine. Bull. Soc. entom. France (1904): 61-64.

- 1905. Description de Coléoptères hétéromères de la République Argentine. Annls. Soc. entom. France 74: 289-303.

Flores, G.E. 1997. Revisión de la tribu Nycteliini (Coleoptera: Tenebrionidae). Rev. Soc. Entomol. Argent. 56 (1-4): 1-19.

- 1999. Systematic revision and cladistic analysis of the Neotropical genera Mitragenius Solier, Auladera Solier and Patagonogenius gen. n. (Coleoptera: Tenebrionidae). Ent. scand. 30 (4): 361-396.

- 2000a. Systematics of the andean genera Falsopraocis Kulzer and Antofagapraocis gen. n. (Coleoptera: Tenebrionidae). J. New York Entomol. Soc. 108 (1-2): 52-75.

- 2000b. Systematic revision of the Argentinean genus Thylacoderes Solier (Coleoptera: Tenebrionidae), with descriptions of two new species. J. New York Entomol. Soc. 108 (1-2): 76-94.

- 2001. Taxonomic placement of the Andean genera Praocidia Fairmaire and Pilobaloderes Kulzer (Coleoptera: Tenebrionidae: Praocini). J. New York Entomol. Soc. 109 (1): 171-178.

- 2004. Systematic revision and cladistic analysis of the Patagonian genus Platesthes (Coleoptera: Tenebrionidae). Eur. J. Entomol. 101(4): 591-608.

- 2007a. New synonymies and lectotype designations in the Neotropical tribes Nycteliini, Praocini, and Scotobiini (Coleoptera: Tenebrionidae). Ann. Zool. 57 (3): 409-426.

- 2007b. Two new species of Psectrascelis (Coleoptera: Tenebrionidae) from western Argentina. Rev. Soc. Entomol. Argent. 66 (3-4): 91-97.
Flores, G.E. \& R. Carrara. 2006. Two new species of Nyctelia Latreille (Coleoptera: Tenebrionidae) from Western Argentina, with zoogeographical and ecological remarks on the high mountain habitat. Ann. Zool. 56(3): 487-495.

Flores, G.E. \& M. Chani-Posse. 2005. Patagonopraocis, a new genus of Praocini from Patagonia (Coleoptera: Tenebrionidae). Ann. Zool. 55 (4): 575-581.

Flores, G.E. \& J. Pizarro-Araya. 2004. Caenocrypticoides triplehorni new species, the first record of Caenocrypticini (Coleoptera: Tenebrionidae) in Argentina, with cladistic analysis of the genus. Ann. Zool. 54 (4): 721-728.

Flores, G.E. \& S. Roig-Juñent. 1997. Systematic revision of the Neotropical genus Entomoderes Solier (Coleoptera: Tenebrionidae). Ent. scand. 28: 141-162.

Flores, G.E. \& P. Vidal. 2000. Cladistic analysis of the Chilean genus Callyntra Solier (Coleoptera: Tenebrionidae), with description of a new species. J. New York Entomol. Soc. 108 (3-4): 187-204.

2001. Systematic revision and redefinition of the Neotropical genus Epipedonota Solier (Coleoptera: Tenebrionidae), with descriptions of eight new species. Insect Syst. Evol. 32 (1): 1-43.

Freude, H. 1967. Revision der Epitragini (Coleoptera, Tenebrionidae). Entom. Arb. Mus. Frey 18: 137-307.

Gebien, H. 1910-1911. Tenebrionidae. In W. Junk \& S. Schenkling (Eds.) Coleopt. Catal. (pars 15): 1-166, 1910; (pars 22): 167-354, 1910; (pars 28): 355-585, 1911; (pars 37): 587-740, 1911. W. Junk, Berlin.

- 1919. Monographie der südamerikanischen Camarien (Coleopt. Heterom.) nebst einer Übersicht über die indischen Gattungen der Camariinen. Arch. Naturg. 83A (3), 1917: 25-167.

- $\quad$ 1926. Zwei neue Gattungen von Tenebrioniden (Col. Heter.) aus Argentinien. Entom. Blätter 22 (2): 82-86.

- 1928. Über einige Gruppen amerikanischer Tenebrioniden (Col. Heter.). Stettiner entom. Zeitg. 89: 97-164, 167-234.

- $\quad$ 1937. Katalog der Tenebrioniden (Col. Heteromera) Teil I. Pubbl. Mus. entom. Pietro Rossi, Udine, Italy 2: 505-883.

- 1938-1948. Katalog der Tenebrioniden (Col. Heteromera) Teil II. Mitt. münchner entom. Ges. 28: 49-80, 283-314, 397-428, 1938; 29: 443-474, 739-770, 1939; 30: 405-436, 755-786, 1061-1092, 1940; 31: 331362, 803-834, 1131-1146, 1941; 32: 308-346, 1942; Teil III. ibidem 32: 729-760, 1942; 33: 399-430, 895926, 1943; 34: 497-555, 1948 [1944].

Haag-Rutemberg, G. 1876. Zur Synonymie. Stettiner entom. Zeitg.37: 108.

International Commission on Zoological Nomenclature (ICZN). 1999. International Code of Zoological Nomenclature, Fourth Edition. Adopted by the International Union of Biological Sciences. International trust for Zoological Nomenclature, London, xxix + $306 \mathrm{pp}$.

Kaszab, Z. 1966. Die Arten der Gattung Lepidocnemeplatia Kaszab (Coleoptera, Tenebrionidae). Entom. Arb. Mus. Frey 17: 39-47.

Kulzer, H. 1954. Neunter Beitrag zur Kenntnis der Tenebrioniden (Col.). Eine Studie über die Tribus Nycteliini. Entom. Arb. Mus. Frey 5 (1): 145-267. 
- 1955. Monographie der Scotobiini. Zehnter Beitrag zur Kenntnis der Tenebrioniden. Entom. Arb. Mus Frey 6 (2): 383-478.

- 1958a. Monographie der südamerikanischen Tribus Praocini (Col.). 16. Beitrag zur Kenntnis der Tenebrioniden. Entom. Arb. Mus. Frey 9 (1): 1-105.

- $\quad$ 1958b. Neue Tenebrioniden aus Südamerika (Col.). 17. Beitrag zur Kenntnis der Tenebrioniden. Entom. Arb. Mus. Frey 9 (1): 184-219.

- 1959. Neue Tenebrioniden aus Südamerika (Col.). 18. Beitrag zur Kenntnis der Tenebrioniden. I. Die Gattung Gyriosomus Guér. (Nycteliini). Entom. Arb. Mus. Frey 10 (2): 523-567.

- 1963. Revision der südamerikanischen Gattung Nyctelia Latr. (Col. Tenebr.) (24. Beitrag zur Kenntnis der Tenebrioniden). Entom. Arb. Mus. Frey 14: 1-71.

Marcuzzi, G. 1976. New species of Neotropical Tenebrionidae (Coleoptera). Annls. hist.-nat. Mus. nation. hungar. 68: 117-140.

Molinari, H.J. 1968. Tenebriónidos nuevos de Jujuy (República Argentina) (Coleoptera - Tenebrionidae). Rev. Soc. Entomol. Argent. 31: 133-140.

Peña, L.E. 1971. Revisión del génro Nycterinus Eschscholtz 1829 (Coleoptera - Tenebrionidae). Boln. Mus. nac., Santiago, Chile 32: 129-158.

- 1973. Insectos de la zona altiplánica de la Argentina. II. El género Pilobalia Burmeister (Coleoptera, Tenebrinidae [sic]. Rev. Soc. Entomol. Argent. 34 (1-2), 1972: 161-176.

- 1974. Nuevas especies y subespecies de Tenebrionidae (Coleoptera) de Chile y de Argentina, con anotaciones sobre nuevas localidades para Argentina, Bolivia y Chile. Boln. Mus. nac. Hist. nat., Santiago, Chile 33: 109-127.

- 1985a. Revisión del género Psectrascelis Fairm. (Solier, sic) (Coleoptera: Tenebrionidae). Rev. Chilena Ent. 12: 15-51.

- 1985b. El género Scelidopsecta Kulzer (1954) (Coleoptera: Tenebrionidae: Nycteliini). Rev. Chilena Ent. 12: 85-89.

- $\quad$ 1986a. Revisión del género Mitragenius Solier (Co- leoptera: Tenebrionidae) con la descripción de tres nuevas especies. Rev. Chilena Ent. 14: 45-56.

- 1986b. Descripción de cinco nuevas especies de Tenebrionidae (Coleoptera) de los géneros Psectrascelis, Platesthes y Thinobatis con una nota adicional. Rev. Chilena Ent. 14: 57-63.

- 1994. Nuevas especies de Tenebrionidae (Insecta Coleoptera) de la región Neotropical. Gayana Zool. 58 (2): 151-168.

- 1995. Revisión del género Physogaster Guérin, 1834 (Coleoptera: Tenebrionidae: Physogasterini). Gayana Zool. 59 (2): 119-130.

Peña, L. E. \& G.P. Barría 1975. El género Oligocara Solier (Coleoptera: Tenebrionidae). Rev. Chilena Ent. 9: 41-44.

Pic, M. 1921. Nouveautés diverses. Mélanges exoticoentom. 34: 1-33.

- 1927. Coléoptères nouveaux ou peu connus de la République Argentine. Rev. Soc. Entomol. Argent. 1 (4): 43-46.

- 1929. Coléoptères de l'Amérique Méridionale. Rev. Soc. Entomol. Argent. 2 (3): 183-184.

- 1930a. Coléoptères nouveaux de la République Argentine. Bull. Soc. zool. France 55: 175-179.

- 1930b. Nouveaux Coléoptères de diverses familles. Rev. Soc. Entomol. Argent. 3 (1): 43-46.

- 1930c. Nouveautés diverses. Mélanges exotico-entom. 55: 1-36.

Pizarro-Araya, J. \& G.E. Flores. 2004. Two new species of Gyriosomus Guérin-Méneville from Chilean coastal desert (Coleoptera: Tenebrionidae: Nycteliini). J. New York Entomol. Soc. 112 (2-3): 121-126.

Semenow, A. 1890. Diagnoses Coleopterorum novorum ex Asia Centrali et Orientali. Horae Soc. entom. ross. 24: 193-226.

Steiner, W.E. 1982. Poecilocrypticus formicophilus Gebien, a South American beetle established in the United States (Coleoptera: Tenebrionidae). Proc. Entom. Soc. Washington 84 (2): 232-239.

Viana, M.J. 1960. Una nueva especie del género Lepidocnemeplatia Kaszab de la República Argentina (Coleop. Tenebrionidae, Cnemeplatiini). Actas y Trab. $1^{\circ}$ Congr. sudamer. Zool. 1959 3: 259-265.

Recibido: 9-VIII-2007 Aceptado: 26-II-2008 